CARLOS H. VERGA, CMF

\title{
LA VICTORIA DEL SALVADOR
}

\author{
Is 63,1-6*
}

\section{Introducción}

El III Isaías nombra a Edom y Bosrá, su capital, sólo en 63,1a, cuando presenta la victoria del Salvador en ese país $(63,1-6)$. El breve texto del que se ocupa nuestro estudio se suma de este modo a la extensa lista de vaticinios y menciones hostiles contra este pueblo, presentes en el corpus propheticum: Is 11,14b; 34; Jr 9,25a; 25,21a; 49,7-22; Ez 25,1214; 35; Am 1,6b.11-12; 9,12a; Jl 4,19a; Ml 1,4a, llamado también Esaú en los vv. 2b.3a; y la profecía de Abdías.

Los oráculos más antiguos de este conjunto, es decir los previos al exilio, como Jr 9,22-25; 25,15-38, unen el destino de Edom al del resto de las naciones, sin que se refleje en ellos motivo de especial encono contra ese pueblo. La situación cambia radicalmente luego del año 587 a.C., debido al colaboracionismo prestado por él durante la invasión de los caldeos a Jerusalén. Los edomitas participaron activamente en el saqueo de la ciudad, mataron a sus fugitivos y anexaron luego parte de Judá a su propio territorio. ${ }^{1}$ De este modo, la fraternidad que unía a ambos pueblos en

* Resumen de la tesis de Licenciatura en Sagrada Escritura realizada en el Pontificio Instituto Bíblico de Roma, en 2005.

1. Cf. B. C. Cresson, "The Condemnation of Edom in Postexilic Judaism", The Use of the Old Testament in the New and Other Essays. Studies in Honour of William Franklin Stinespring (ed. J. M. Efird), Durham - 1972,142-143. J. R. BARTLETT, Edom and the Edomites, JSOTS 77, Sheffield - 1977, 151-157, en cambio, da cuenta de una visión totalmente distinta sobre el rol actuado por Edom durante el 587 a. C. en Jerusalén. 
un pasado religioso común quedó hecha añicos. ${ }^{2}$ La memoria colectiva de Israel ligó el recuerdo de Edom al de Babilonia y proyectó sobre ambos su odio más feroz.

Los oráculos de Ezequiel permiten inferir el progresivo destacarse de Edom del resto de los países vecinos. Ambos son acusados por delitos semejantes. Pero mientras a estos últimos se les da esperanzas de vivir, para Edom el único destino posible es convertirse en una desolación (cf. Ez 25,12-14 en el conjunto de 25-32 y la profecía de Ez 35, durante la segunda etapa de su ministerio).

Los oráculos más virulentos contra Edom fueron forjados en la época del exilio. Están teñidos con los rasgos propios de la escatología apocalíptica, y siguen el modelo de los anuncios relacionados con la suerte final de Babilonia, acaecida en el 539 a.C. Así, Is 34 retoma a Jr 50-51 y 49,7-22; y en estos oráculos también se inspira el breve texto de Is 63,16 (cf. Jr 25,30; 49,9). Abdías, por su parte, compone su profecía-memorial en base a Jr 49,7.9-10.12.14-16.22; Ez 35,1.5.13.10; 36,12; Am 1,11b12; 9,12; Jl 4,12.17b; Mi 4,7b. Su composición testimonia la espiral de violencia creciente contra los edomitas: la justicia divina deberá aniquilar, necesariamente, al victimario de su pueblo y lo hará de un modo u otro. ${ }^{3}$

Los oráculos del exilio y del post-exilio contra Edom y Babilonia manifiestan una polaridad que les es característica: "castigo - regreso del destierro" o "destrucción - restauración"; el trasfondo de la misma es la justicia retributiva: Al castigar de modo ejemplar a Edom y Babilonia, el Señor venga su pueblo de la afrenta recibida y abre un horizonte de paz y prosperidad al Israel reconciliado, por el establecimiento firme y definiti-

Para ello se basa en Jr 40,11 y en la ausencia de acusaciones concretas en los oráculos de Is 34 y Ml 1,2-5, así como en la adición de Jl 4,19. Pero el conjunto de los oráculos contra este país tuercen la evidencia en otro sentido. Por su parte, F. DelitzsCH, "Biblical Commentary on the Prophecies of Isaiah", Isaiah (ed. C. F. Keil - F. Delitzsch), Commentary on the Old Testament in Ten Volumes VII, Grand Rapids - 1980, II, 444, aún sin negar el carácter "representativo" -no simbólico- de todo el mundo hostil a Israel en cuanto tal que tiene Edom, parece justificar la enemistad tomando por históricas las tradiciones del Génesis sobre la primogenitura de Jacob sobre Esaú.

2. Cf. BARTLETT, Edom, 187.194-200.

3. Los instrumentos del castigo varían de uno a otro oráculo: Nabucodonosor y Babilonia (Jr 25,9); las naciones (Jr 49,14); Israel (Ez 25,14; Am 9,11-12; Ab 18ss); un fuego devorador (Am 1,12); o el Señor en persona (Is 34,2; 63,3; Ez 35,15; Jl 4,21; Ml 1,4). vo en Sión. Tal polaridad puede manifestarse en una misma profecía (cf. Is 11,10-16), o conformar un díptico entre dos anuncios (cf. Is 34-35 y Ez 35,1-36,1-15). En J1 4,18-21 aparece enmarcada en el horizonte escatológico de la restauración definitiva de Judá. Avanzado ya el establecimiento de la comunidad del post-exilio en Jerusalén, en una época cargada de decepción, cuando la realidad mina existencialmente las razones de la esperanza, Malaquías intenta movilizar, por medio de ella, la conciencia religiosa de Israel (cf. Ml 1,2-5). El apelo a la polaridad de destinos resalta el amor preferencial del Señor por su pueblo, en lugar de Esaú, desde el inicio y para siempre.

Is 63,1-6 se nutre de la memoria colectiva de Israel y de esta corriente profética contra Edom. Se apropia, además, de algunas de sus imágenes más significativas, especialmente algunas de Jeremías (cf. 25,15-17.30.31). La fuerza evocadora del oráculo parece cumplir lo anunciado en Is 34. Con todo, si nuestro texto describe la victoria del salvador en territorio edomita, hay que reconocer que, con esto, no necesariamente pretende indicar un determinado acontecimiento histórico semejante al de la caída de Babilonia, o el establecimiento de un nuevo orden político. $\mathrm{Su}$ testimonio profético apunta, ante todo, al imaginario simbólico del pueblo y a la conciencia por la cual éste se reconoce amado por el Señor.

\section{Delimitación del texto}

Is 63,1-6 se inserta estructuralmente en la segunda mitad del III Isaías y conforma una unidad textual perfectamente delimitada. El centro del libro está ocupado por la vocación y la misión del profeta: ungido y enviado al servicio de una palabra que es liberación, cura y consuelo para los afligidos de Sión (61,1-3a). Los efectos de tal misión se prolongan en un oráculo de salvación $(61,3 b-9)$ y en un canto de acción de gracias, como respuesta al anuncio del profeta $(61,10-11)$, que prepara el nuevo noviazgo del Señor con Jerusalén (Is 62). Is 63,7-64,11 forma una cierta unidad vinculada temáticamente con el capítulo 59. YHWH, siempre dispuesto a salvar y a escuchar $(59,1)$, ha favorecido en todo momento "a la casa de Israel" con su bondad y su amor sin medidas $(63,7)$. Pero la salvación ofrecida ha encontrado rebeldía como respuesta y ha hecho que el Señor la trate como enemiga suya $(59,2-8 ; 63,10)$. La confesión del pecado en Is 59,9-15 se puede parangonar con la declaración de la culpa y la 
invocación de 64,4b-11. Esta toma de conciencia ante Dios tiene lugar después que el orante ha considerado los hechos portentosos realizados por el Señor en favor de su pueblo (63,11-14), y luego de una primera súplica al Padre para que cambie de actitud (v. 17b); pues el profeta se lamenta de que el Dios celoso, fuerte, y lleno de ternura (vv. 15-16), haya cerrado sus entrañas ante quien lo invoca (v. 15) y endurecido el corazón de sus siervos, permitiéndoles que se separen de él (v. 17a).

El estilo de Is 63,1-6 rompe con la forma de los textos que lo encuadran. Es un diálogo entre dos o más personas que, por su cercanía con Is 62,6-7 y como reclamo del mismo, bien podrían identificarse con los "centinelas" puestos sobre las murallas de Jerusalén para recordar al Señor en todo momento, y hasta cansarlo, su compromiso en el restablecimiento de Jerusalén. La breve conversación $(63,1-2)$ introduce la presentación del salvador victorioso que, tomando la palabra, describe su gesta liberadora (vv. 3-6).

El texto juega con la imagen del viñador que pisa la uva (dārak, vv. $2.3[2 \mathrm{x}]$; bûs, v. 6) en el lagar (v. 2) o en la cuba (v. 3) y con el jugo rojo de la sangre de "ellos" (niṣhām, vv. 3.9), los pueblos (v. 6; como en v. 3) que él ha derramado por tierra (v. 6), y que le ha salpicado, manchando sus vestidos (l'bûš, v. 2; $\boldsymbol{b}^{\boldsymbol{e}}$ gādîm, vv. 1.2.3; malbûš, v. 3).

La imagen del vino se retoma en el v. 6 con el verbo šăkar ("emborrachar"). Pero aquí, lo que ha embriagado a los pueblos no es ningún tipo de bebida alcohólica sino la ira del salvador ('ap, vv. 3.6) y su furor (hēmāh, vv. 3.5.6). Sólo él y la fuerza de su brazo han sido el apoyo que lo ha sostenido al obrar su salvación (sāmak, v. 5[2x]).

Con el adverbio 'āyin (vv. 3.5[2x]) el texto pone de relieve la soledad de tal empresa. Que nadie actuara a su lado en ese momento lo deja pasmado (̌̌mm Hitpolel, v. 5). La doble mención del adjetivo zeh en la pregunta del v. 1 acrecienta la tensión del relato y la curiosidad del lector. Pero se rompe con la presentación que el misterioso personaje hace de sí

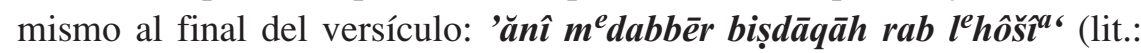
"yo, uno que habla con justicia, grande para salvar"). La llegada del liberador que viene (v. 1) se debe a que "había (ha) llegado el día planeado de la venganza y el año de mi rescate" (v. 4). Es destacable el uso de la raíz 'dm como señalamiento geográfico, en el v. 1, y para indicar el color rojo que da lugar a la explicación del salvador, en el v. 2.

Vistas las características específicas del vocabulario, la acción descrita por el texto, las imágenes que utiliza, y su estructura, podemos afir- mar que Is 63,1-6 forma una unidad textual perfectamente delimitada dentro del contexto en el que se ubica.

Dos reclamos importantes de nuestro oráculo dentro de su horizonte textual, Is 59,15b-20 e Is 61,1-3, se destacan: el primero es el asombro del Señor frente a la soledad de su intervención liberadora (Is 59,16; $63,5)$; el segundo, la misión del profeta "enviado a proclamar un año de gracia del Señor y un día de venganza de nuestro Dios” $(61,2 ; 63,4)$.

\section{Traducción}

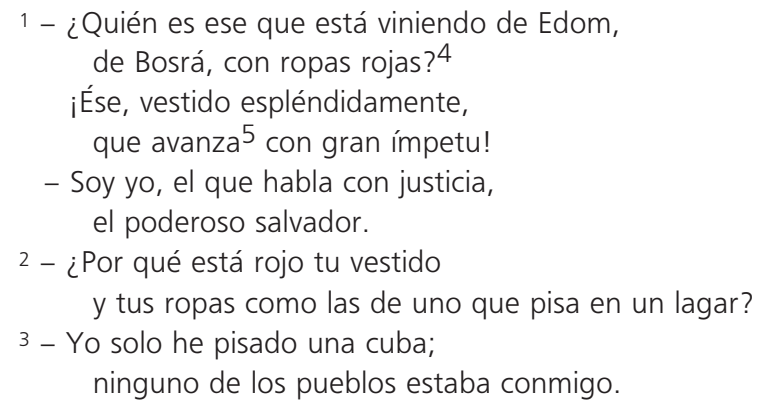

4. Cualquier traducción que reemplace los nombres de Edom y Bosrá en Is 63,1 buscaría armonizar el texto con la imaginería del viñador que en él se presenta, a riesgo de descuidar su fuerza evocadora. Así, la conjetura propuesta por De Lagarde - considerada genial por Westermann, aunque no adhiera a ella - propone el participio Pual $\mathrm{m}$. s. de 'ādôm, "enrojecido", por Edom (v. 1a), y repite así la raíz del "rojo" de los vestidos (v. 2); una forma testimoniada en Na 2,4 al referir el choque militar de la caída de Nínive (Na 2,4-14). Por su parte, $\boldsymbol{m i n}+$ participio Qal m s de bāṣar "vendimiar", como alternativo de Bosrá (v. 2), no tiene testigos en la BH. Cf. C. WESTERMANN, Isaia (capp. 40-66), Antico Testamento 19, Brescia - 1978, 454.

5. Según D. BARThéLemy, Critique textuelle de l'Ancien Testament. 2. Isaïe, Jéremie, Lamentations, OBO 50/2, Fribourg - Göttingen - 1986, II, 430, s̄a ‘ $\overline{\boldsymbol{a}} \boldsymbol{h}$ es "la única lectura firmemente testimoniada" y șa 'ad, en cambio, es considerada por él una exégesis de la primera; pero quizás por eso mismo la forma alternativa es más comprensible y guarda mayor coherencia con el versículo. Para una discusión de la variante, cf. J. L. Koole, Isaiah III. 3. Isaiah Chapters 56-66, Historical Commentary on the Old Testament, Leuven - 2001, 333-334. 
Los pisé con mi rabia

y los aplasté con mi furia;

su jugo salpicó mis ropas

e hice que se mancharan todos mis vestidos.

4 Porque había llegado el día de venganza planeado,

el año de mi rescate.

${ }^{5}$ Miré, pero no había quien ayudara;

me sorprendí de que no hubiera uno que apoyase:

así que me salvó mi brazo

y mi furia fue la que me sostuvo.

6 He pisoteado a los pueblos con mi rabia

con mi furia los he emborrachado;

y he derramado su jugo en la tierra.

\section{Formkritik de Is 63,1-6}

\subsection{Ambiente sintáctico, estilístico y estructural}

Is $63,1-6$ es una composición poética con la forma de un "diálogo de centinelas". Su contenido evidencia una estructura tripartita: (1) Diálogo inicial (vv. 1-2); (2) Metáfora vitivinícola (vv. 3-5); (3) Síntesis explicativa de la metáfora (v. 6). ${ }^{7}$

Is 63,1-6 inicia con un diálogo motivado por la pregunta: $m \hat{\imath}-z e h$, “QQuién es ése?” La cercanía de nuestro texto con 62,6a y el contenido del diálogo posterior, hacen pensar en la guardia apostada sobre las murallas de la ciudad, que controla sus entradas y salidas de la ciudad. ${ }^{8}$ La pregun-

6. Seguimos aquí la propuesta de H. SimiAn-Yofre, "Diacronía. Los métodos histórico-críticos", Metodología del Antiguo Testamento (ed. H. SimianYofre), Biblioteca de Estudios Biblicos 106, Salamanca - 2001, 107-114. "Crítica de la forma" no se refiere por tanto a las "formas" literarias originales sino al texto escrito y a cada uno de sus aspectos propiamente lingüísticos. Por motivos de mayor exactitud, cada uno de los términos citados se indican, en esta sección y en la que presenta el horizonte textual de Is 63,1-6, según el número de su versículo y el orden alfabético castellano para cada uno de sus verbos. En el resto del trabajo, y sólo cuando es necesario, se señala "a" o "b" luego del número del versículo; según el 'aṭnāh del Texto Masorético.

7. Para la estructura poética del pasaje y su métrica, cf. H. ODEBERG, Trito-Isaiah. A Literary and Linguistic Analysis, UppsArsskr 1, Lundequistska Bokhandeln - 1931,17; P. D. HANson, The Dawn of Apocalyptic. The Historical and Sociological Roots of Jewish Apocalyptic Eschatology, Philadelphia - 1975, 203

8. Así también Westermann, Isaia, 453; Koole, Isaiah III, 328-329. ta determina los verbos participiales de los primeros versículos ubicándolos en el ámbito del presente, con su solemnidad característica. Un centinela ve que alguien se está acercando en ese preciso instante y le pide, le exige, que se identifique. Se trata de un grito parecido al “¡Alto! ¿Quién vive?" de la guardia del ejército. La repetición del adjetivo zeh (v. 1) añade intensidad y suspenso al interrogante inicial, a la vez que nuevos detalles a la descripción. Ése que el guardia ha identificado como "viniendo de Edom", y más precisamente de Bosrá, vestido de rojo, ése que avanza con ímpetu y cuyo ropaje es espléndido; ése debe identificarse.

El forastero irrumpe en la escena y responde de modo breve, conciso y enigmático: "Yo, uno que habla con justicia; grande para salvar". Y ante tal respuesta el centinela no tiene ya necesidad de ahondar más sobre la identidad del salvador. Para sorpresa del lector -o de quien escucha el relato-, su atención se centra ahora en las manchas de las ropas que el liberador trae puestas (v. 2). Más allá del aparente absurdo, su curiosidad es fuente de preciosa información: el rojo no es el color natural de su ropa, sino que "hay rojo en ella"; está roja "como la de uno que pisa la uva".

La disposición quiástica de los dos primeros versículos (A:

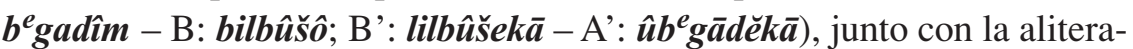

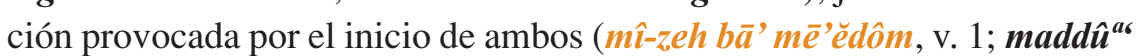
'âdōm, v. 2), resaltan la respuesta del personaje principal, que es también su presentación y casi una declaración.

El verbo dārak con el sustantivo que le sigue, al final del v. 2, "pisar (en el lagar)", son el pie para la explicación metafórica con que responde el salvador en el v. 3: "una cuba (he pisado)". 9 A partir de ahora (vv. 3-6), la acción se sitúa en el ámbito del pasado. Los verbos en imperfecto (vv. 3b.c.d.5a.c.6a.) añaden vivacidad a los detalles sincrónicos narrados por el personaje (cf. 6,4). Los complementos del verbo dārak, "pisar", en el v. 3, indican el modo y las circunstancias de la acción: "yo solo" (v. 3a) y "con rabia" (v. 3b). El v. 3a tiene su paralelo en 5a.b.c.d. Y la misma disposición tiene v. 3b.c con v. 6a.b y v. 3d con v. 6c. En ellos también se evidencia cierta progresión gradual tanto en la acción violenta del personaje como en sus sentimientos: la tercera vez no se usa därak sino rāmas (v. 3c), es decir "hollar", "dar pisotones fuertes" y, figuradamente, "atropellar", "tratar sin consideración" o "maltratar" (cf. Is 1,12; 16,4; 41,25; 2

9. Cf. G. SAUER, "דרך", THATI, 649. 
Re 7,17.20). Al final, en el v. 6, el verbo bus, "pisotear", ofrece una síntesis de su relato.

La sinonimia acentúa la intensidad de la acción y permite entrever la emoción interior del personaje. La disposición paralela de los vv. 3.5.6 ofrece además una mirada retrospectiva sobre los acontecimientos. ${ }^{10} \mathrm{La}$ respuesta pasa de la pregunta (v. 3) a las causas (v. 4) y de éstas a la interioridad del que habla (v. 5).

El k̂â explicativo del v. 4 encierra el núcleo más significativo del diálogo hasta ahora realizado: "el día planeado para mi venganza y el año de mi rescate ha llegado". El sufijo pronominal de $1^{\text {a }}$ persona singular "mi", que determina la venganza y el rescate (v. 4), particularizan estos conceptos de modo único. La preposición $\boldsymbol{b}^{\boldsymbol{e}}$ denota el espacio mental interior ( $\boldsymbol{b}^{\boldsymbol{e}} \boldsymbol{l} \boldsymbol{i} \boldsymbol{i} \boldsymbol{b} \hat{\boldsymbol{\imath}}$, "en mi corazón") donde la venganza toma su forma. En cambio, en la auto-presentación del v. $1, \boldsymbol{b}^{\boldsymbol{e}}$ indica la condición concomitante a su dibbēe "uno que habla con / en justicia".

La repetición de los lexemas resalta:

a) La soledad de la empresa realizada y el vigor del héroe: 11 "yo solo" (v. 3a); "no había nadie conmigo" (v. 3a); "no había uno que ayude" (v. 5 b); "no había uno que apoye" (v. 5d); "me salvó mi brazo" (v. 5e); "me sostuvo mi furia" (v. 5f).

b) La violencia de su acción y la fuerza empleada: "pisar" (vv. 2.3a.b); "aplastar" (v. 3c); "pisotear" (v. 6a); "mi brazo" (v. 5e); "mancharse completamente ( $\boldsymbol{k} \overline{\boldsymbol{o}} \boldsymbol{l})$ la ropa (con sus salpicones de sangre)" (v. 3d.e); "embriagar (de furia)" (v. 6b); "derramar (su sangre)" (v. 6c).

10. F. Holmgren, "Yahweh The Avenger. Is 63:1-6", Rhetorical Criticism. Essays in Honour of James Muilenburg (ed. J. J. Jackson - M. Kessler), PTMS 1, Pittsburgh - 1974, 135-136, ve en estos versículos un nuevo quiasmo y habla de una doble disposición quiástica del texto: vv. 1-2; 3-6.

11. J. S. CROATTO, Imaginar el futuro. Estructura retórica y querigma del Tercer Isaías (Isaías 56-66), Buenos Aires - México - 2001, 332, entiende esta "solitud" declarada -"de los pueblos no había nadie conmigo"- como una elipsis por "los dioses de los pueblos" en una interpretación contextual al libro de Isaías. Su opinión se propone en contraposición a la de WESTERMANN, Isaia, 455-456, que ve en dicha afirmación un rasgo mítico, proveniente de la concepción de la lucha contra el caos, un duelo como el de Marduk contra Tiamat y sus acólitos descrito en el Enuma Elish. Pero tal vez lo mejor sea interpretar la expresión tal como la presenta el texto, como una referencia a los pueblos extranjeros que, en otras ocasiones, también habían sido instrumentos del castigo del Señor. Cf. 3:1, n. 3. c) Sus sentimientos encontrados: "miré y me asombré" (v. 5a.c); "mi rabia" (vv. 3b.6a); "mi furia" (vv. 3c.5f.6b).

d) La cohesión en la imagen vitivinícola: "pisar la uva" (vv. 2.3[2x]); "una cuba" (v. 3); "un lagar" (v. 2); "su jugo" (que salpica o se derrama en tierra, vv. 3a.6c); "emborrachar" (v. 6b). Es de notar que la raíz consonántica de Bosrá (bṣr) se usa en otros textos para indicar justamente la acción de vendimiar (cf. Is 6,9; 49,9; Ab 5).

La última frase del pasaje explica sintéticamente la metáfora: la ausencia de "los pueblos" ( 'ammîm, v. 3) se debe a que éstos son el objeto de la venganza ('ammîm en acusativo, v. 6). No pueden, por tanto, servirle de ayuda en esta ocasión.

Las palabras "ropa" y "vestido" retoman y mantienen, en la segunda parte del diálogo (v. 3d.e), el hilo de la primera (vv. 1b.c.2). La aliteración provocada entre el verbo gā'al, "manchar", en Hifil (v. 3e), y el sustantivo ge'ûlay, "mi rescate" (v. 4), juega con el sentido de estas palabras. El verbo bô', "venir", al final de éste, forma una inclusión con el primer participio del v. 1 y se predica tanto del día de venganza como del año para redimir.

A su vez, es posible establecer algunas correlaciones entre la metáfora y el resto del texto: Edom y Bosrá son el punto de partida de su recorrido y la cuba donde el vengador pisa las uvas, es decir, los pueblos. El jugo de aquéllas es una metonimia por la sangre de éstos; y el vino que los embriaga, la furia del liberador. El viñatero es un poderoso salvador ( $\boldsymbol{r} \boldsymbol{a b}$

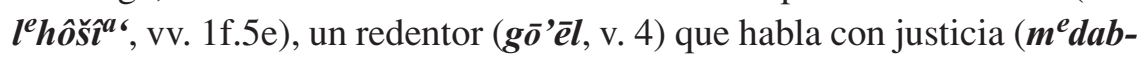
bēr biṣdāqāh) y cuya identidad permanece velada. La majestad característica de sus vestidos, el brío con que avanza y el poder de su brazo salvador hacen pensar en un rey poderoso o un guerrero.

EN RESUMEN. Is 63,1-6 es una poesía en "forma" de diálogo de centinelas. ${ }^{12}$ Introduce una metáfora sobre la llegada de un día de venganza y un año de redención previstos por un poderoso salvador. El texto transmite una vitalidad y una fuerza desmedida e impresionante. Las manchas de la ropa y el testimonio del liberador describen lo sucedido en Edom como una auténtica borrachera de sangre.

12. Así también Westermann, Isaia, 453. Odeberg, Trito-Isaiah, 17, en cambio, considera que se trata de un salmo litúrgico en forma de visión apocalíptica y emparentado con Is 24-27; 34-35; Sal 24,7-10. Un diálogo similar, probablemente entre un pueblo (que podría ser Edom) y un centinela (el profeta), es presentado por Is 21,11-12. Cf. CRESSON, "Condemnation", 138. 


\subsection{Ambiente semántico}

En primer término, nos centraremos en la determinación geográfica del texto para resaltar la procedencia del liberador que viene "de Edom" (mēéédôm, v. 1b). En segundo lugar, estudiaremos los tres conceptos fundamentales transmitidos en las respuestas de los vv. 1.4: "hablar

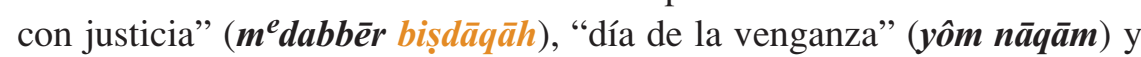

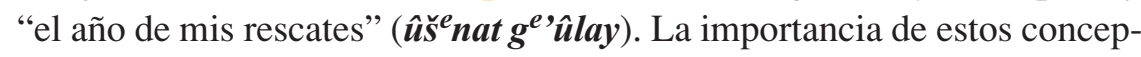
tos los liga con otros afines, presentes en el mismo texto.

\subsubsection{El Señor viene "de Edom"}

Edom estaba situado en la región montañosa ubicada al este de la Arabá; desde el extremo sudeste del Mar Muerto hasta el borde norte del golfo de 'Aqaba. David lo anexó a su reino (cf. 2 Sam 8,13-14), pero el país reconquistó su independencia bajo el reinado de Jorán de Judá (848841 a.C.; cf. 2 Re 8,20-22).

El libro del Génesis hace descender a los edomitas de Esaú, el hermano de Jacob (cf. Gn 25,19-36,43). Y la Biblia le reserva un trato especial en relación con las demás naciones extranjeras. Posiblemente se pueda atribuir este hecho a un pasado religioso común con el yavismo que posteriormente se desarrolló en Israel (1 Sam 21,8). De hecho la Sagrada Escritura no dice casi nada sobre la religión edomita: no identifica por nombre algún dios al cual se rindiera culto en ese territorio, ni describe a los habitantes del país como hijos de algún dios (como hace con los moabitas en Nm 21,29). Tampoco presenta algún tipo de sacrificio o ritual propio de este pueblo. ${ }^{13}$

Dos referencias semánticas halladas en los libros de Jueces y de Habacuc presentan al Señor avanzando desde el territorio de Edom. Se trata del cántico de Débora (Jue 5,4) y la oración hímnica con la cual Habacuc cierra su libro (Ha 3,3). Ambos son considerados como las poesías hebreas más antiguas. ${ }^{14}$

El cántico entonado por Débora y Barac en Jue 5, a propósito de la muerte de Sísara (cf. 4,17-24), celebra la avanzada del Dios Guerrero que

13. Cf. BartLetT, Edom, 175-180.194-200; C. R. Mathews, Defending Zion. Edom's Desolation and Jacob's Restoration (Isaiah 34-35) in Context, BZAW 236, Berlin - New York - 1995, 70-75.

14. Cf. Bartlett, Edom, 197; Mathews, Defending Zion, 75-76. a su paso provoca un cataclismo cósmico. YHWH avanza victorioso sobre sus enemigos junto con los héroes y heroínas de su pueblo. ${ }^{15} \mathrm{El}$ himno de Ha 3, por su parte, ensalza al Dios Guerrero de dimensiones cósmicas y rasgos apocalípticos. Su presencia enciende el entusiasmo del profeta y renueva su confianza: él espera que el Señor salve a su pueblo de los enemigos que lo acechan: de las naciones (v. 12b), del impío y su casa (v. 13b), de sus guerreros (v. 14a), y del pueblo que nos asalta (v. 16). ${ }^{16}$

Isaías, por su parte, también presenta otras tres alusiones al Dios Guerrero y sus victorias en 42,10-13; 49,24-25; 52,10.

El primer texto, Is 42,10-13, está estructuralmente ubicado en la primera parte del II Isaías $(40,12-48,22)$. Es un himno que invita al cosmos y a todos los pueblos con sus habitantes a alabar al Dios Guerrero que sale como un héroe para enfrentar con coraje al enemigo.

Los otros dos pasajes pertenecen a la segunda parte del libro (49,1-55,5): Is 49,24-25 forma parte de un oráculo sobre la fidelidad eterna de Dios $(49,14-26)$. El anuncio responde a tres objeciones presentadas por Jerusalén: su olvido y abandono (vv. 14-20); su soledad y esterilidad (vv. 21-23); su cautividad (vv. 24-26). Según el pasaje, los opresores de la ciudad santa, derrotados por el Señor, reconocerán con ella que el redentor y salvador de Jerusalén es “el fuerte de Jacob” (v. 26b).

El último texto, Is 52,10, es un canto al Señor que reina victorioso (52,7-12). El rescate de Jerusalén es consuelo para su pueblo y manifiesta el poder de Dios ante las naciones y ante toda la tierra.

EN RESUMEN. El recorrido geográfico descrito en Is 63,1-6 evoca al Dios Guerrero de los antiguos cánticos, al Dios de las gestas de Israel. Victorioso sobre las naciones enemigas, el Señor avanza desde el territorio de Edom. La imagen, calcada de las poesías épicas del pueblo, retoma

15. Este texto es importante porque integra la esfera cósmica del Dios guerrero al plano histórico de las tribus de Israel y las mujeres que combaten contra sus enemigos; un punto crucial en el nacimiento de la perspectiva profética testimoniada en la poesía épica más antigua. La integración de la perspectiva cosmológica en el plano histórico, en una tensión dinámica es, según P. D. HANsoN, "Old Testament Apocalyptic Reexamined", Visionaries and Their Apocalypses (ed. P. D. Hanson), IRT 2, Philadelphia - London - 1983, 40-41, uno de los logros más propios y la característica más destacada del profetismo en Israel.

16. Cf. R. N. WhYBRAY, Isaiah 40-66, NCBC, Grand Rapids, MI - London - 21981, 227. 
algunos trazos con que el II Isaías presenta al Señor cuando ejerce su rescate y manifiesta su victoria ante los pueblos, ante todo el universo.

\subsection{2. "Hablar en justicia"}

Entre los variados usos que Isaías da al sustantivo $\underline{s}^{e} \boldsymbol{d} \bar{a} q \bar{a} \boldsymbol{h}$ ("honradez", "rectitud", "derecho", "justicia", "inocencia", "piedad", "salvación", "liberación", 31 veces en todos sus escritos), encontramos un discurso del Señor, en primera persona, que puede iluminar el ámbito semántico de Is 63,1 . Se trata de Is 45,18-25, una "invitación a las naciones". Allí aparecen, en dos oportunidades, el sustantivo ş $\boldsymbol{s}^{e} \boldsymbol{d} \overline{\boldsymbol{q}} q \overline{\boldsymbol{a}} \boldsymbol{h}$ y su sinónimo sedeq junto a la raíz $\boldsymbol{d b r}$, sustantivo y verbo ("hablar", "palabra"). En esta oportunidad, el Señor declara literalmente: "de mi boca ha salido honradez, una palabra que no volverá atrás" $(45,23)$. La presentación inicial está construida de modo semejante a la de nuestro texto (dāabar, en Qal participio + sedeq): "Yo soy el Señor, digo lo que es justo" $(45,19)$.

El pasaje pertenece a la primera parte del II Isaías, donde se hallan los escritos sobre la liberación y el regreso de los desterrados a Jerusalén $(40,12-48,22)$. Su contexto inmediato anterior reporta la elección e investidura de Ciro -ungido por el Señor- para someter a las naciones (45,1-7), y un breve himno que resalta la fecundidad creadora del Señor por la cual hace brotar la justicia y la salvación (v. 8). La elección de Ciro ha sido determinada por el poder soberano de YHWH sobre la creación y la historia. Es un poder que sólo admite como respuesta la confianza y el reconocimiento de sus criaturas (vv. 9-13). Incluso el resto de las naciones se verán obligadas a confesar que sólo en Israel está el único Dios, que no existen otros dioses (v. 14); y se convertirán a él (vv. 14-17). Los capítulos que siguen señalan, por una parte, la ineficacia de los ídolos y la fidelidad de Dios (Is 46); por otro, la caída de Babilonia (47).

En Is 45,18-25 el Dios creador, que ha dirigido a la descendencia de Jacob su palabra clara e irrevocablemente (vv. 18s), convoca a comparecer a todos los sobrevivientes de las naciones. Los llama para que expongan sus pruebas y deliberen juntos. Para que confronten su capacidad de salvar con la de los ídolos (vv. 20s). El argumento con que prueba que nadie, excepto él, es el Dios justo y salvador, es el cumplimiento de sus antiguas predicciones (v. 21). En razón de ello invita a que las naciones se conviertan a él (v. 22) para hacerlas partícipes de un destino universal e inexorable (vv. 23s) que es la gloria de Israel (v. 25). El contenido de la justicia que aquí proclama el Señor refiere la veracidad de lo que anuncia: un plan de salvación de alcance universal, predicho desde antiguo. Un proyecto destinado a cumplirse por la eficacia de su poder, para vergüenza de sus adversarios.

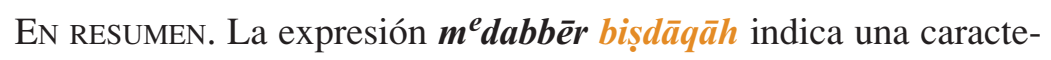
rística específica del Dios de Israel. Lo confronta con todo lo que no es Dios y, por tanto, inútil. Señala a YHWH como el único Dios capaz de salvar, cuyos decretos son eficaces. ${ }^{17}$ Evidencia, por contraste, la ignorancia de quienes ponen su confianza en los ídolos u otros dioses. $\mathrm{Y}$ es esto lo que reclama para sí el misterioso personaje de Is 63,1 al presentarse. Su respuesta no deja lugar a dudas: es el Señor, el Dios de Israel. El diálogo posterior probará la eficacia de sus decretos al referir la venganza llevada a cabo en Edom.

\subsection{3. "El día de la venganza"}

El sustantivo yôm, "día", en singular, aparece 90 veces en el libro de Isaías. Además de su significado propio, puede designar diversas divisiones del tiempo, o transformarse en un concepto temporal -prolongado o concreto, como en nuestro texto- de importancia decisiva. ${ }^{18}$ Junto a Is 34,8 e Is 61,2 , el v. 4 del capítulo 63,4 es el tercer y último caso en que yôm se presenta en estado constructo con $\boldsymbol{n} \bar{a} q \bar{a} \boldsymbol{m}$ y hace referencia al "día de venganza".

Tanto en Is 34,8 como en la narración sobre la misión del profeta de Is 61,2 el concepto temporal "día de venganza" está, a su vez, determi-

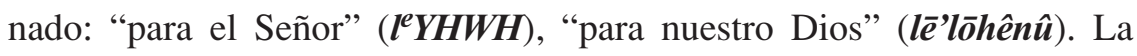
expresión se transforma de este modo en un concepto teológico de capital importancia: el del "día del Señor". La forma aparece sólo en Is 13,6.9

17. HANSON, "Apocalyptic Reexamined", 42, señala que los profetas clásicos toman muy en serio el ámbito histórico como ámbito primario de la actividad divina; como parte de la alianza establecida por YHWH y de su interacción con su comunidad. El carácter genuino de tal interacción proviene de que, en la profecía, la actividad salvadora de YHWH se reconoce en los eventos de la historia. Así, la traducción que Croatto hace de la expresión $\boldsymbol{m}^{\boldsymbol{e}} \boldsymbol{d a b b} \overline{\boldsymbol{e}} \boldsymbol{r}$ bișdāqāh explica adecuadamente la idea contenida en la respuesta del liberador, aunque anticipa lo que sigue y la polariza en el ámbito de la

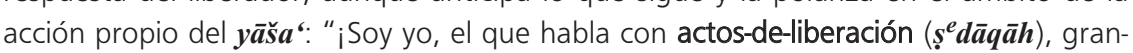
de para salvar!". Cf. J. S. CROATTO, Imaginar, 329.

18. Cf. E. JeNNI, "ירם", THATI, 975-1000. 
(oráculo contra Babilonia, Is 13,1-22). En ese día Dios será implacable: destruirá a los caldeos y convertirá la tierra en un desierto, exterminando de ella a los pecadores.

Tal y como aparece en 34,8 y 61,2, la expresión se presenta también en Is 2,12: un oráculo sobre la actividad judicial del día de YHWH contra todo lo soberbio, engreído e idolátrico; un día en el cual sólo y únicamente el Señor será exaltado. Finalmente, sin el nombre divino, como en 63,4, pero evidenciando diversas características de su manifestación divina, encontramos los siguientes matices: en Is 10,3 hace referencia a un día de castigo para los explotadores; en 13,13 es un día de enojo y ardiente ira; para Is 22,5 se trata de un día de aflicción, abatimiento y confusión; 30,25 lo presenta como el día de la gran matanza; y en 17,11 es el día de la desgracia. Todas las expresiones acentúan rasgos particulares de la intervención de Dios en el decurso de la historia. La mayoría de los casos señalados son una profecía abierta al futuro.

También Joel y Lamentaciones expresan la actividad judicial del Señor con imágenes parecidas a las del viñador. Jl 4,13 invita a que los cosecheros y lagareros metan guadaña y pisen la uva. La cosecha está ya madura, y es tan abundante que los toneles desbordan "de maldad". El contexto del oráculo es el juicio a las naciones en el valle de Josafat (Jl 4,117). "Porque está cerca el día del Señor en el valle de la Decisión" (v. 14b), todos reconocerán quién es el Señor, su Dios, que habita en Sión (v. 17a).

Lm 1,15, por el contrario, presenta a Jerusalén como la que ha sido pisada, como las uvas, por el Señor. Su misma destrucción es un juicio que la hace recapacitar sobre su conducta rebelde y la inocencia de su Dios (v. $18 \mathrm{a}) .{ }^{19}$

En nuestro texto (Is 63,4), el nomen regens nāqūm, "venganza", es un sustantivo derivado del verbo de la misma raíz (vengar). Su significado originario ha de relacionarse con el ámbito jurídico en el cual una injusticia se suprime y compensa por medio del castigo "privado". Tiene por objeto personas que están fuera del ámbito del derecho y del poder

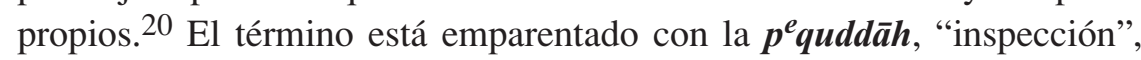
"represalia"; pero se diferencia de ella. El verbo pāqad, "inspeccionar", señala la investigación escrupulosa de las circunstancias de un delito en el ámbito del propio poder, para proceder en consecuencia. ${ }^{21}$ El ejemplo

19. Cf. WesteRMANn, Isaia, 454-455.

20. Cf. G. SAUer, "נקם", THAT II, 146-149.

21. Cf. J. SCharbert, "Venganza", Enciclopedia de la Biblia VI, 1164-1166. paradigmático de la venganza es el del "vengador de la sangre", el gō'ē haddām, el pariente más próximo de un muerto o una mujer ultrajada, cuya sangre debía ser rescatada con la muerte de su asesino o agresor, sin que se le impute la culpa (Nm 35,27; 2 Sam 3,27; 13,32). Con todo, la Ley de Santidad (Lv 17-26), al prohibir la venganza entre compatriotas (Lv $19,18)$, corrige esta práctica del derecho consuetudinario del pre-exilio. ${ }^{22}$

No siempre es posible distinguir rigurosamente el sentido profano del sentido religioso del $\boldsymbol{n} \bar{a} q \bar{a} \boldsymbol{m}$ (cf. Nm 31,2; 2 Sam 4,8). El justo encomienda al Señor el castigo de sus enemigos, ya que éstos son también enemigos de Dios (Jr 11,20; 12,3). Al castigar a los enemigos de Israel, Dios venga a su pueblo (cf. Dt 32,41-43). En Isaías, además de los textos ya citados $(34,8 ; 61,2 ; 63,4)$, encontramos otros relacionados con el $\boldsymbol{n} \bar{a} q \bar{a} \boldsymbol{m}$ : cf. Is 35,$4 ; 47,3 ; 59,17$. En todos estos pasajes, el vengador es siempre el Señor. Los textos pertenecen al período del exilio o del post-exilio. Al analizarlos, es posible descubrir en el lexema nāqām la bipolaridad característica de los oráculos de este período. La venganza sirve tanto para castigar a los culpables: las naciones enemigas y los adversarios, como para consolar a las víctimas: los desterrados y la gente que ha quedado en Jerusalén.

Nuestro texto abunda en los sentimientos de "cólera" (hēmāh) y de "ira" ('ap) que acompañan al concepto de "venganza". El sustantivo hִêmāh deriva del verbo $\boldsymbol{y} \overline{\boldsymbol{a}} \boldsymbol{h} \boldsymbol{h} \boldsymbol{a m}$, que quiere decir "estar en celo"; básicamente significa "arder de pasión". Apunta en primera lugar al sentimiento interior de cólera y agitación de quien se predica. El vocablo 'ap, por su parte, designa la exteriorización corporal y sensible de la indignación interna. Tiene que ver con la manifestación que se evidencia, incluso, en la respiración agitada de quien está enojado. ${ }^{23}$

El II Isaías une ambos sustantivos en dos textos: en Is 42,25 , cuando refiere la ceguera y la sordera de Israel ante la salvación y la enseñanza del Señor (que derramó sobre él "el ardor de su ira"; 42,18-25), e Is 66,15 donde indica que "el ardor de su ira" llegará para juzgar a los que van detrás de cultos idolátricos. Para el II Isaías, la rabia y la furia divinas desatadas contra Israel son consecuencia directa de su incapacidad para comprender la salvación de Dios $(42,21)$ y obedecer su enseñanza

22. Cf. R. J. Faley, "Leviticus", NJBC, 73

23. Cf. G. SAUER, "חמלו", THATI, 807-809. 
(42,24s). En el III Isaías, esa incapacidad tiene relación con ciertas prácticas cultuales de carácter sincretista e idolátrico, al parecer, llevadas a cabo en Jerusalén (cf. Is 65,2-7.11; 66,17; Ez 8).

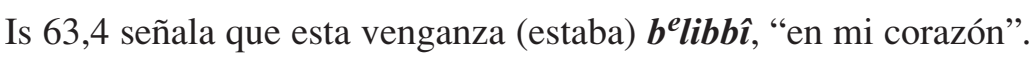
La elipsis de la construcción sobreentiende el verbo "estar", tal como ocurre en Is 51,7 donde "mi ley (está) en su corazón”. Lēb no designa aquí el "corazón" en tanto que órgano del cuerpo humano, sino lo más propio de la persona que habla. Cuando el sustantivo se presenta como en nuestro caso, precedido por la preposición $\boldsymbol{b}^{\boldsymbol{e}}$ y acompañado por un sufijo personal, indica los pensamientos íntimos y rara vez comunicables de una persona; se trate de un hombre o una mujer cualesquiera o del mismo Dios. ${ }^{24}$

EN RESUMEN. El campo semántico de la expresión yôm nāquām en Is 63,4 tiene que ver con el "día de YHWH" y sus notas de premeditación, furor, violencia y, muy especialmente, de manifestación de la justicia divina; incluso más allá de los límites de su territorio. Se trata de un día de juicio y castigo para los enemigos del Señor -israelitas o extranjeros- o, como en nuestro caso, para los pueblos extranjeros, asesinos de su gente; pero también, y a la vez, día de consuelo para las víctimas y/o de resarcimiento para la parte que resultare ofendida por una determinada acción; se trate de un ultraje al pueblo de Dios o al honor de éste.

\subsection{4. "El año de mi rescate"}

El sustantivo šānāh en estado constructo ("año de") es utilizado por el III Isaías sólo en 63,4 y en 61,2 para indicar el contenido de la procla-

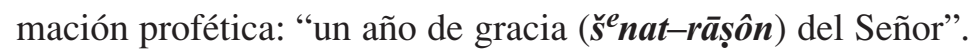

$\boldsymbol{G}^{\boldsymbol{e}} \boldsymbol{\text { ûlay, }}$, por su parte, no deja de presentar cierta ambigüedad: se puede interpretar como Qal pasivo de $\boldsymbol{g} \overline{\boldsymbol{a}} \boldsymbol{\prime} \boldsymbol{a l}$ (participio plural + sufijo de $1^{\text {a }}$ s.): "mis redimidos", igual que en Is 35,9; 51,10 (en estado absoluto), e Is 62,12 (en estado constructo con YHWH), o como sustantivo abstracto, en acusativo singular, "un año para la redención", o en plural con sufijo, "el año de mi rescate". 25 Como quiera que sea la elección que se haga, la raíz hebrea g'l, "redimir", "rescatar", es la clave para acceder al sentido de la expresión.

24. Cf. E. Jenni, "לב", THATI, 1176-1185.

25. Cf. F. BRown, "גאול "ליל", BDB, 145.
El término $g^{\prime} \boldsymbol{l}$ proviene del ámbito jurídico y, a pesar de haber pasado posteriormente al vocabulario del culto y al lenguaje religioso-teológico, ha mantenido siempre el significado acuñado por el derecho tal como aparece en Lv 25. Allí, la Ley de la Santidad, prevé e instituye, además del año sabático (vv. 1-7), del año jubilar (vv. 8-17) y de la promesa para el año sabático (vv. 18-22), el rescate de la propiedad del israelita empobrecido que se haya visto obligado a vender su herencia por necesidad. El rescate ha de efectuarse por medio de un $\boldsymbol{g} \overline{\boldsymbol{o}}$ ' $\overline{\boldsymbol{e}} \boldsymbol{l}$ que restituya la propiedad a su primer dueño (vv. 23-38), y efectivice la liberación de los esclavos israelitas que hayan pagado sus deudas vendiéndose al servicio de otro (vv. 39-55). ${ }^{26}$

El II Isaías aplica a YHWH el ejercicio de rescate propio del $\boldsymbol{g} \overline{\boldsymbol{\sigma}}$ 'ēl: en Is 43,1; 44,22-23; 48,20; 52,3.9; y es él quien atribuye al Señor, por primera vez, el título de "redentor" (cf. Is 41,14; 43,14; 44,6.24; 47,4; 48,17; $49,7.26 ; 54,5.8)$. De este modo, el concepto jurídico-familiar se transforma en concepto teológico. El Señor rescata a su pueblo como si fuera uno de ellos y, por el ejercicio del derecho que tiene sobre su propiedad, lo recupera para sí. En esta misma línea se ubican los textos del III Isaías sobre YHWH redentor: Is 59,20; 60,16; y 63,16.

Pero en la legislación de Israel existía, además de los dos tipos de rescate anteriormente citados, el de la redención de la sangre, tal como hemos visto a propósito del yôm nāqūm, "día de venganza". En efecto, Nm 35 (cf. también Dt 19,1-13 y Jos 20,1-9) prescribe sobre las "ciudades de refugio" destinadas a los homicidas que hubieran matado a alguien involuntariamente con la finalidad de ponerlos a salvo del gō'ēl haddām, la persona jurídica encargada de matar al homicida cuando lo encontrara, se tratase de un israelita, un extranjero o un residente del país ( $\mathrm{Nm} 35,15)$. La ley indica que la vida de un asesino que obra deliberadamente no se puede rescatar ni perdonar bajo ninguno de los aspectos contemplados por la instrucción para los homicidas involuntarios. Quien es encontrado culpable de homicidio voluntario debe ser declarado reo de muerte y debe morir (vv. 30-32). El derramamiento de sangre profana la tierra que sólo es purificada cuando corre en ella la sangre del asesino (v. 33).

La capacidad de venganza manifestada por el Señor revela también

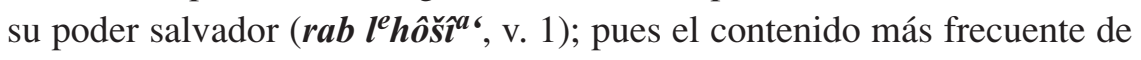

26. Cf. נ. J. StÁmM, "גאל", THATI, 549-564 
su salvación es precisamente la facultad que tiene para impartir la justicia. ${ }^{27}$ El verbo $\boldsymbol{y} \overline{\boldsymbol{a}} \boldsymbol{s}^{\mathbf{a}}$ ", "salvar", "liberar", entra así a formar parte del mismo campo semántico. El término es usado en la casuística jurídica para designar la ayuda debida a la víctima de una violación que clama pidiendo auxilio (cf. Dt 22,27). En el II Isaías indica la acción específica que diferencia a YHWH de los ídolos y los dioses "que no pueden salvar" (cf. 45,17.20.22; 46,7). En el v. 5 b de nuestro texto (Is 63,1-6), la raíz

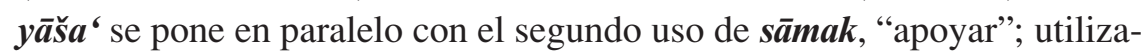
do por primera vez como paralelo de 'āzar (v. 5a), con el significado traslaticio de "socorrer, ayudar".28

EN RESUMEN. El campo semántico de la expresión $\breve{s}^{\boldsymbol{e}} \boldsymbol{n a t} \boldsymbol{g}^{\boldsymbol{e}} \boldsymbol{\boldsymbol { u }} \mathbf{u}$ lay queda enmarcado específicamente dentro del ámbito jurídico. Alude al derecho que el Señor tiene para rescatar al pueblo de su propiedad. Con todo, Is 63,1-6 no especifica a qué tipo de rescate se refiere; a juzgar por el plural, se podrían incluir todas las redenciones aún pendientes. Pero a diferencia del II Isaías y de los textos citados del III Isaías, a excepción de 59,20 , por la violencia reseñada en nuestro relato, la referencia al derramamiento de la sangre de los pueblos $(63,6 \mathrm{c})$ junto con las consideraciones hechas sobre el yôm nāqūm, y los datos que ofrecen los oráculos con-

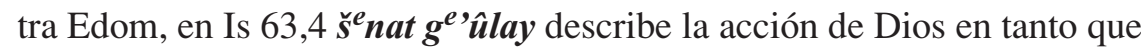
ḡ̄ồl haddām. ${ }^{29} \mathrm{Su}$ venganza restituye la sangre inocente derramada por las naciones, especialmente la que hicieron correr los edomitas, y purifica a su vez la tierra profanada por sus homicidios.

\subsection{Conclusión sobre la Formkritik de Is 63,1-6}

El breve poema de Is 63,1-6 es un icono de la justicia divina. El diálogo y la metáfora vitivinícola dan cuenta, en primer lugar, de la justicia de la acción salvadora de YHWH más allá de los confines de su pueblo. Con el estilo propio del III Isaías, 30 el texto retoma dos hilos principales que entretejen la trama de Is 56-66 y de todo el libro de Isaías: el de la justicia y el derecho.

27. Cf. F. StOLz, "שיע", THATI, 1078-1085.

28. Cf. F. STOLz, "ספ"מע", THAT II, 212-215.

29. Cf. Holmgren, "Avenger", 145-148; Westermann, Isaia, 456.

30. Cf. OdeBERG, Trito-Isaiah, 272-276. R. N. WhyBRAY, Isaiah, 226 no lo ve del mismo modo. Para él, Is 63,1-6 tal como está, es un elemento extraño y escasamente apropiado a un contexto de forcejeos internos de la comunidad judía, pero el análisis del horizonte textual no dice lo mismo.
Los atributos con que el Señor se presenta en Sión ("un poderoso liberador que habla con justicia") no hacen más que confirmar la intuición que despierta su avanzada aguerrida desde Edom; un nombre en el que la memoria colectiva de Israel conjuga las victorias del Dios Guerrero y la hermandad traicionada por el fratricidio y la apropiación de la herencia del Señor. Su breve presentación no deja lugar a equívocos: el Señor, en persona, frente a las murallas de Jerusalén, declara a los guardias que ya ha llegado el día de venganza que tenía previsto y el año para su rescate.

Las manchas de su ropa, signo evidente de la cruenta batalla en el país del Sur, son el testimonio cierto de la justicia -planificada y llevada a cabo por Dios- contra las naciones. El Señor solo y únicamente él restituye a la nación amada la dignidad que había perdido por el ultraje de las naciones. Él es el $\boldsymbol{g} \overline{\boldsymbol{o}}$ 'êl que rescata el pueblo de su propiedad. Y es sobre todo el $\boldsymbol{g} \overline{\boldsymbol{\sigma}}$ 'êl haddām que con su venganza redime la sangre derramada y purifica la tierra con la sangre de los asesinos. La eficacia de la Palabra del único Dios verdadero no defrauda.

Is 63,1-6 cumple los oráculos de Is 34; 41,25-26 y se coloca en el amplio contexto de los oráculos proféticos del exilio y del post-exilio que prevén el juicio de las naciones y Edom.

Con la imaginería profética de la vitivinicultura y el lagar, el III Isaías actualiza la llegada del Dios Guerrero y Victorioso de antaño -que a su paso aniquila sus enemigos- y lo pone a las puertas de Jerusalén.

\section{Is 63,1-6 en el horizonte textual del III Isaías}

Dos ejes temáticos, complementarios entre sí, articulan el horizonte textual de Is 63,1-6. El primero está constituido por los avances y retrocesos en la llegada de la salvación prometida y lo que esta situación provoca en el profeta. Es que la salvación inminente que se había anunciado a fines del exilio no termina de hacerse presente en la realidad concreta de la Jerusalén del post-exilio. El segundo tiene que ver con el compromiso en la práctica de la justicia, en medio de una realidad injusta. Un empeño que tiene que ver tanto con la comunidad jerosolimitana y su gente, como con el Señor.

\subsection{La salvación llega a Jerusalén}

Is $63,1.4$ recoge dos expresiones de su contexto anterior inmediato: 
62,11c: hinnēeh yiš' $\bar{e} \boldsymbol{k} \boldsymbol{b} \overline{\boldsymbol{a}}$ '

(= Mira, tu salvación está llegando)

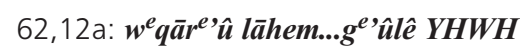

(= y los llamarán... rescatados de/ Señor) 63,1a: $\boldsymbol{m} \hat{\boldsymbol{\imath}}-\boldsymbol{z} \boldsymbol{e h} \boldsymbol{b} \overline{\boldsymbol{a}}$

\section{3,1e: 'ănî...rab l'hôš̂îa}

(= Soy yo... el poderoso salvador)

\section{3,4: $\hat{\text { ušenat }} \mathbf{g}^{\boldsymbol{e}}$ '̂ulay}

(= y el año de mi rescate)
(= ¿Quién es ese que está llegando?)

Is $62,11 \mathrm{c} .12 \mathrm{a}$ forman parte del segundo grupo de textos del III Isaías (Is 60-62). En ellos se evidencia un optimismo semejante al del II Isaías (cf. Is 51,11.17a; 52,1-10; 54): el nuevo orden socio-político mundial enciende el entusiasmo profético por una nueva era, creada por YHWH, para la nueva Jerusalén que está gestando. La esperanza se abre paso ante el regreso de los desterrados, por un lado, y a causa de la promesa de la gloria del Señor amaneciendo -brillando- sobre Jerusalén, como una aurora que ilumina a todos los pueblos, por otro $(60,1-4)$.

En el capítulo 62 el profeta presenta la ciudad como novia y esposa del Señor (vv. 1-5), y a sus centinelas como los que recuerdan ¡a Dios! sus promesas de restauración (vv. 6-9). En los vv. 10-12 el III Isaías se dirige, alternadamente, al pueblo que regresa del destierro (vv. 10a.b.12a), y a Jerusalén (vv. 10c.d.e.f.g.12b). ${ }^{31}$

Los imperativos del v. 10 urgen al pueblo para que atraviese las puertas de la ciudad y entre en ella ('ibrû, 'ibrû); y exhorta a sus habitantes a abrir el camino del pueblo (pannû derek $\boldsymbol{h} \overline{\boldsymbol{a}}{ }^{‘} \overline{\boldsymbol{a}} \boldsymbol{m}$ ). Dios hace oír su mensaje hasta el confín de la tierra (hišmi ${ }^{a \bullet}$, v. 11). El profeta, a su vez, lo transmite a "la hija de Sión". Tres hinnēh ("he aquî", "mira") dan actualidad, vivacidad e importancia a la noticia (v. 11). YHWH proclama que llega su salvación. Que trae con él su salario y delante de él, su recompensa. La forma participial del verbo bồ , "venir" (Qal m. s., "está viniendo"),

31. Simian-Yofre señala algunos elementos comunes entre el prólogo del II Isaías $(40,1-11)$ e Is 62,10-12: (a) un destinatario plural; (b) el uso de los imperativos $(40,1.9$; 62,10); (c) la exhortación pannû derek $(40,3 ; 62,10)$; (d) el triple hinneh; (e) la llegada (del Señor, 40,10; del salvador, 62,11); (f) "salario-recompensa" (40,10b; 62,11b). Cf. H. SIMIAN-YOFRe, La teologia del Profeta Isaia. Dispense per uso esclusivo degli studenti, Roma - 2005, 32-33. Is 62,10-12 también tiene elementos en común con Is 11,10-16 (oráculo sobre el regreso de los desterrados) e ls 35 (oráculo sobre el regreso a Sión); en 11,12a el Señor levantará un estandarte ante las naciones (cf. 62,10g); habrá una $\boldsymbol{m}^{\boldsymbol{e}}$ ssilāh para el pueblo $(11,16 ; 62,10 \mathrm{e})$. En Is 35,9 se indica que "los rescatados" ( $\boldsymbol{g}^{\boldsymbol{e}}$ '̂̂lîm) volverán a Sión; y en 62,12 a el nombre dado al pueblo que regresa será "el pueblo del Santo" ( 'am-haqqōdeš) y "los rescatados del Señor" (g $\boldsymbol{g}$ 'ûlê $\mathbf{Y H W H}$ ). junto con el sustantivo y sufijo de 2 f. s. $\boldsymbol{y} \boldsymbol{y i s}^{\mathbf{s}} \overline{\boldsymbol{e}} \boldsymbol{k}$, "tu salvación”, referido a Jerusalén, es un nexo entre este pasaje y lo que describe nuestro texto. Is 62,11 anuncia y prepara la llegada inminente del Señor.

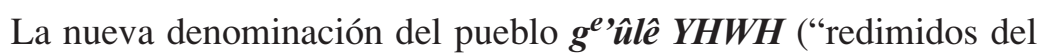
Señor"), en 62,12a, también liga ambos textos entre sí. La realidad futura del pueblo, que el nombre indica, es el resultado de la intervención directa de Dios a favor del pueblo que rescata con su redención y su venganza $($ Is 63,4$)$. El Señor actúa conforme al ejercicio del derecho; es por tanto una obra de justicia.

La misma idea es presentada en Is 60,16b, el oráculo sobre Jerusalén, luz de las naciones, del capítulo 60. Allí el Señor se señala a sí mismo como

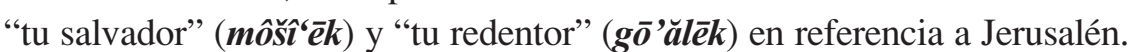
La forma $\boldsymbol{m} \hat{\boldsymbol{o s}} \mathbf{\imath}{ }^{\mathbf{e}} \overline{\boldsymbol{e}} \boldsymbol{k}$, aplicada a YHWH, se encuentra también en Is 43,3 (oráculo de salvación para Israel, Is 43,1-7); y en 49,26b (sobre la fidelidad eterna de Dios, Is 49,14-26). En el primero, la actividad salvadora del Señor es la de un $\boldsymbol{g} \overline{\boldsymbol{\sigma}}$ 'êl que rescata su pueblo a un precio muy alto (v. 4), y se dispone a reunirlo de nuevo (vv. 6-7). En el segundo, la expresión de 60,16b sólo

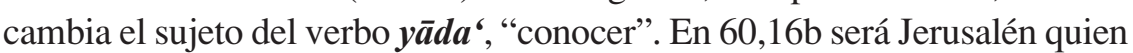
reconozca a YHWH como su salvador y redentor. En 49,26b, en cambio, serán "todos" (kol-bāśấr) los que lo reconocerán de esa manera. 49,26b: $w^{e} y \bar{a} d^{e}$ 'û kol-bāśär kî̀ 'ănî YHWH

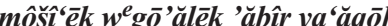
Y sabrán todos que yo soy $\mathrm{YHWH}$ tu salvador y tu redentor, el Fuerte de Jacob.

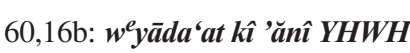

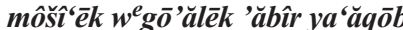
Y sabrás que yo soy $\mathrm{YHWH}$ tu salvador y tu redentor, el Fuerte de Jacob.
El título ’ăbîr ya‘ŭqōb, "el Fuerte de Jacob", es uno de los tres nombres que Jacob da a YHWH, cuando bendice a José (Gn 49,22-26), antes de morir. ${ }^{32}$ Es usado en Is 49,26; 1,24 (oráculo contra la prostitución de Israel, Is 1,21-26) en estado constructo con yiśr $\bar{a}$ 'ēl en lugar de 'ăbîr. Los dos pasajes comparten tanto la imagen del Dios que se venga y desquita de sus enemigos, como el rol fundamental que juegan la fidelidad o la infidelidad de Jerusalén, de sus jefes, de Dios.

Un detalle de importancia, que parece condicionar (o al menos convertirse en un prerrequisito para) la llegada de la salvación, es la exhorta-

32. Los otros dos son "Pastor" (rō'eh) y "Roca de Israel" ('eben yiśr ä' ēl; Gn 49,24b). 
ción a preparar el camino del pueblo. Is 62,10 presenta siete verbos en imperativo. Tres de ellos tienen relación directa con dicha preparación:

a) "Preparen el camino del pueblo" (= pānāh , imperativo Piel m. p. + derek acusativo constructo con $\boldsymbol{h} \overline{\boldsymbol{a}} \boldsymbol{\top} \overline{\boldsymbol{a}} \boldsymbol{m})$;

b) “Allanen el sendero" (= sālal [2x] imperativo Qal m. p. + ham ${ }^{e}$ silläh acusativo);

c) "Quiten de (él) la(s) piedra(s)" (= sāqal, imperativo Piel m. p. + Preposición min + 'eben).

El oráculo de salvación de Is 57,14-21 puede iluminar el sentido de la preparación. En él YHWH explica el castigo por el que ha pasado el pueblo (vv. 16-17) y promete que lo sanará, lo guiará y le dará su consuelo, a pesar de haber visto "sus caminos". La expresión indica aquí del modo de proceder del pueblo. Esta perspectiva "ética" del camino es reafirmada al inicio y al final del oráculo. El v. 14a presenta las mismas formas verbales que Is 62,10 (Imperativo Qal de sālal [2x] y Piel de pānāh, constructo con derek). Los vv. 20-21 contraponen la suerte de los malos, que no tienen paz (vv. 20-21), con la paz que cantará el pueblo que él consuele (v. 18).

Pero en qué consiste concretamente esa ética y cómo ha de prepararse el pueblo para la llegada de la salvación del Señor, no está indicado en ninguno de los dos textos. La respuesta se debe buscar en la predicación del III Isaías. La encontramos en los reclamos textuales que se dan entre Is $56,1-2 ; 62,11 ;$ y 63,1 :

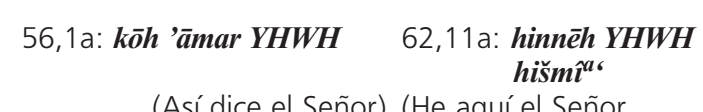

56,1c: wa'ăśû ș $\boldsymbol{s}^{e} \bar{a} q \bar{a} h$

(y practiquen la justicia)

$$
\begin{aligned}
& \text { 56,1e: } \boldsymbol{w}^{e} \text { șidquātî l'higgālōt } \\
& \text { (mi justicia } \\
& \text { está por manifestarse) }
\end{aligned}
$$

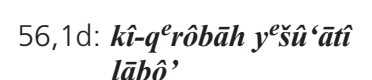

(porque se acerca mi salvación)

62,11c: hinnēh yiš' 'êk b $\boldsymbol{b}$ '

(Mira, tu salvación está llegando) 63,1e: 'ănî $\boldsymbol{m}^{\boldsymbol{e}} \boldsymbol{d a b b \overline { e } r}$ bișdāqāh

(soy yo, el que habla con justicia)

63,1a: $\boldsymbol{m i \hat { \imath } - z e h} \boldsymbol{b} \overline{\boldsymbol{a}}$,

(¿Quién es ese que esta llegando?)

63,1e: 'ănî...rab l'hôšša

(Soy yo... el poderoso salvador)
El III Isaías exhorta en nombre de Dios; la llamada inicial no es una idea que le pertenece $(56,1 \mathrm{a})$; hasta el confín de la tierra resuena el anuncio que debe ser transmitido a Jerusalén, en 62,11a.b). "Observar el derecho y practicar la justicia" $(56,1$ b.c), se revela como un mensaje fundamental en el ministerio profético del III Isaías; tanto por su ubicación, como por la autoridad que se invoca al transmitirlo. Su importancia está avalada por la bienaventuranza que Dios ofrece a todo el género humano ('ašrê 'ěnôš ya'ăśše-zō't ûben-'âdām yahăzîq bāH, 56,2a).

A nivel sintáctico, la bienaventuranza está ligada a la exhortación que la precede ("dichoso el que observe el derecho y practique la justicia") por el pronombre demostrativo $\overline{\boldsymbol{z}} \overline{\boldsymbol{o}} \boldsymbol{t} \boldsymbol{t}$, “esto", y la preposición $\boldsymbol{b}^{\boldsymbol{e}}+$ sufijo 3 f. s., "en ella"; cf. v. 1b.c. Pero también está unida a lo que sigue después de ella: "dichoso el que se cuide de no profanar el Sábado, y el que se cuide de no hacer algún tipo de mal" (v. 2b.c). De este modo, la bienaventuranza, en tanto que ofrecida a todos los seres humanos, es universal; pero sólo accederán a ella los que se empeñen en vivir de acuerdo a este tenor de vida.

Vivir de este modo significa predisponerse para acoger la salvación del Señor que se acerca, y la revelación de su justicia. La exhortación inicial del III Isaías no es un mero precepto que se agota en sí mismo. La razón principal para vivir conforme al derecho y practicar la justicia es la cercanía inminente de la manifestación del Señor: $\boldsymbol{k} \hat{\boldsymbol{\imath}}-\boldsymbol{q}^{\boldsymbol{e}} \boldsymbol{r} \hat{\boldsymbol{o}} \boldsymbol{b} \overline{\boldsymbol{a}} \boldsymbol{h} \boldsymbol{y}^{\boldsymbol{e}} \mathrm{s}^{\mathbf{u}}{ }^{`} \overline{\boldsymbol{a}} \boldsymbol{t} \hat{\boldsymbol{\imath}}$

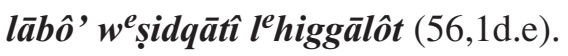

La predicación del III Isaías articula, desde el inicio, dos ejes temáticos fundamentales de su profecía. Is 56,$1 ; 62,11 ; 63,1$ describen el itinerario progresivo de su llegada a Jerusalén. Is 56,1d proclama: la salvación del Señor (mi salvación) está, lit. "cercana, para venir” y su justicia ( $m i$ justicia), "para revelarse" (v. 1e). En este pasaje el anuncio queda abierto al futuro y, de alguna manera, indeterminado. Is 62,11 anuncia, en cambio, un mensaje destinado a Jerusalén, pero que "el Señor hace oír hasta el confín de la tierra": la salvación de Jerusalén (tu salvación) es un hecho evidente (triple hinnēh): No sólo se siente por todos lados, sino que la misma ciudad lo puede ver. Es, además, un acto de justicia: la salvación se presenta con su salario y su recompensa. En Is 63,1, el Señor en persona aparece a las puertas de la ciudad, y se identifica: "Soy yo, el que habla con justicia, el poderoso salvador" $(63,1$ a.e).

EN RESUMEN. La llegada del Señor y de su salvación se presenta en estos textos como un hecho inminente e inexorable. La cuestión ética, es decir, pro- 
ceder rectamente o no hacerlo, parece no condicionar su venida; aunque sí el acceso a la bienaventuranza prometida (56,1-2); hasta tal punto, que el criterio de juicio con el cual el Señor discriminará la suerte final de los miembros de su pueblo, será justamente si han respondido a sus llamados, obedecido a sus palabras u obrado conforme a lo que es de su agrado (Is 65,12).

\subsection{Sin justicia no hay salvación}

Otras referencias textuales vinculan a Is 63,1-6 y al oráculo del capítulo 59 que queda orgánicamente articulado y comprendido en el mismo horizonte textual:

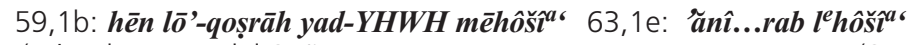

(Mira, la mano del Señor no es corta para salvar)

(Soy yo... el poderoso salvador)

59,3b: śiptôtêkem dibb rêu šeqer (vuestros labios hablaron mentiras)

63,1e: ‘̆ầ $\boldsymbol{m}^{e}$ dabbēr bișdāqāh

(Soy yo, el que habla con justicia)

59,4d: $\boldsymbol{w}^{\boldsymbol{e}}$ dabber-šā $\boldsymbol{w}^{\prime}$

59,13d: dabber-'̄ošeq

(y hablar falsedad)

(hablar de opresión y rebelión)

59,13f: $\boldsymbol{w}^{\boldsymbol{e}} \boldsymbol{h} \overline{\boldsymbol{o} g} \hat{\boldsymbol{o}}$ millēb dibrê-šāqer

(murmurar interiormente palabras

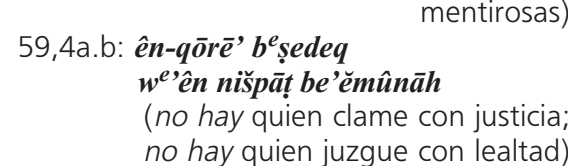

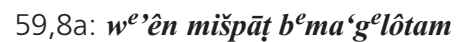

(en sus sendas no existe el derecho)

59,11d: neqawweh lammišspạt wä'ayîn

(esperábamos el derecho, en cambio, nada)

59,15f: wayyēra' b'êê̂aw kî-'ên mišspàt (le pareció mal que no existiera el derecho)

\section{9,16a.b.c: wayyar' kî̀-'ên 'îs}

wayyištômēm kî 'ên mapgîa

(y vio que no había nadie, se asombró

de que no hubiera quien interviniese)

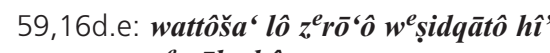
$\boldsymbol{s}^{e} \boldsymbol{m} \bar{a} \boldsymbol{k} o t h \hat{u}$

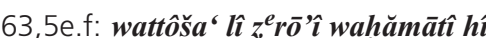

(así que lo salvó su brazo y su justicia fue la que lo sostuvo)

\section{$\boldsymbol{s}^{\boldsymbol{e}} \boldsymbol{m a} \bar{a} k o t n \hat{\imath}$}

(así que me salvó mi brazo y mi furia fue la que me sostuvo) 59,11d: lîsî ‘āh rāhăqūh mimmennû

(la salvación está lejos de nosotros)

59,17a.b: wayyilbaš s $\boldsymbol{s}^{\boldsymbol{e}} \boldsymbol{d a} q \bar{a} \boldsymbol{h}$ șašširyon

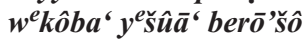

wayyilbaš bigdê nāqūm tilbōšet

(y vistió la justicia como coraza, y la salvación en su cabeza, y vistió romo un yelmo;

59,3a: kî kappêkem $\boldsymbol{n}^{\boldsymbol{e}} \mathbf{g} \overline{\boldsymbol{o}}$ ălû baddām (sí, las palmas de sus manos se han manchado

\section{3,1b.c: hămûs b $\boldsymbol{b}^{e}$ gādîm...} zeh hadar bilbûšó

(ropas rojas... ése, vestido espléndidamente)

63,2: maddûa' 'ādōm lilbûšekā ûb ${ }^{\boldsymbol{e}}$ gaděkā $k^{e} d \bar{o} r \bar{e} k b^{e}$ gat

(¿Por qué está rojo tu vestido, y tus ropas como las de uno que pisa en

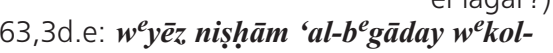
con la sangre) malbûšay 'eg'āltî

(su jugo salpicó mis ropas e hice que se mancharan todos mis vestidos) 63,4a: kî yôm nāqūm b libbî

(porque el día de venganza planeado)

59,18a: hēmāh $\boldsymbol{l}^{e}$ șārâw

(furia para sus enemigos)

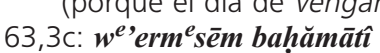
(y los aplasté con mi furia) 63,6b: wa'ăkke rēm bahămātî (los he emborrachado con mi furia)

Is 59 comienza con una proposición que, en primera instancia, se debe colocar en la misma línea del resumen anterior: "Mira, no es corta la mano del Señor para salvar (mēhôšš ${ }^{a}$ ); ni está embotado su oído para escuchar" (v. 1). Los capítulos 58 y 59 de Isaías se hallan relacionados entre sí; y la sentencia de Is 59,1 retoma, en segunda instancia, la pregunta de Is 58,3a: “¿Para qué ayunamos, si no ves? Nos humillamos, pero no te enteras". Una primera respuesta dada por el Señor, a través del profeta, se encuentra en 58,3b-7. Ahora, en Is 59,2, el III Isaías, en parte, la profundiza, y en parte, reorienta la problemática cultual (Is 58) al denunciar el pecado social y, especialmente, las trampas de la injusticia imperante.

Si la Jerusalén del post-exilio vive una situación de no-salvación, y Dios parece despreocuparse de su suerte, no es porque no esté dispuesto a salvar o escuchar a su gente. El valor adversativo de $\boldsymbol{k} \hat{\boldsymbol{\imath}}$ 'im ("al contrario", $59,2 a$ ) indica claramente que las causas de la no-salvación han de buscarse en las rebeldías y los pecados de la descendencia de Jacob, que el profeta debe denunciar sin contenerse $(58,1)$. 
Is 59,1-2 presenta, por tanto, una tesis: los pecados y la maldad del

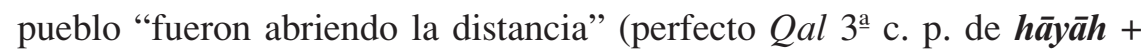
participio Hifil m. p. de $\boldsymbol{b} \overline{\boldsymbol{a}} \boldsymbol{d a l}$ ) entre ellos y su Dios, e hicieron que Dios ocultara (Hifil perfecto $3^{\mathrm{a}}$ c. p. de sātar) de ellos su rostro (pānîm), para no escucharlos (prep. $\boldsymbol{m i n}+$ šāma Qal inf. ctr.). El verbo šāma', "oír", retoma aquí la cuestión de la escucha divina presentada en Is 58,4.9.33

El v. 3 está unido al anterior por un $\boldsymbol{k} \hat{\boldsymbol{\imath}}$ aseverativo, por los sufijos de $2^{\text {a }}$ m. p., "ustedes", y por el sustantivo ‘̄̄wôn, "iniquidad”, “culpa”. Es el inicio de una larga prótasis que se extiende hasta el final del v. 8. En ella el profeta denuncia las culpas y los pecados de la casa de Jacob, y pone en paralelo dos expresiones que describen el pecado del pueblo en relación con el cuerpo humano; como si toda la descendencia de Jacob fuera una sola persona.

Con la imagen de las manos (kappêkem, "las palmas de ustedes";

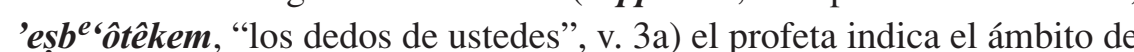
la acción humana; lo describe contaminado ("se han contaminado", $\boldsymbol{n}^{\boldsymbol{e}} \boldsymbol{g} \overline{\boldsymbol{o}} \boldsymbol{a} \boldsymbol{a} l \hat{u}$, perfecto Nifal) con la sangre y por la culpa de los crímenes. La misma denuncia se encuentra en v. 6b: "Sus obras son obras de iniquidad; hay actos de violencia en las palmas de sus manos". Tanto 59,3 como 63,3e utilizan el verbo gā'al (Hifil) para dar cuenta de las manchas, es decir su contaminación de las manos y de los vestidos, respectivamente. La diferencia entre uno y otro pasaje está en el hecho que provoca el derramamiento de la sangre: en el primer caso, una obra de iniquidad; en el segundo, una obra de justicia.

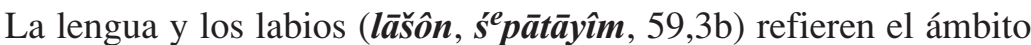
de la palabra (especialmente en los juicios) distorsionado por la injusticia ( 'awlāh) y por la mentira (̌̌eqer). El cuádruple uso de $\boldsymbol{d} \boldsymbol{b} \boldsymbol{r},{ }^{34}$ en estado constructo con sustantivos que expresan rasgos negativos, muestra hasta

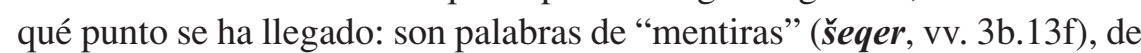

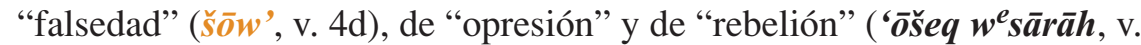
13d). El dābar humano ha sido despojado de su característica más genui-

33. Is 1,15 presenta una temática parecida, con reclamos textuales importantes. Se relaciona explícitamente con la oración que el Señor desoye porque "las manos - de los orantes- están llenas de crímenes".

34. Como verbo Piel perfecto, en el v. 3b, e infinitivo absoluto, en los vv. 4d.13d; como sustantivo con hgh, "murmurar", como en 3, en el v. $13 \mathrm{f}$ na: su capacidad de comunicar, de testimoniar, de crear comunión. Vaciado de significado mina la confianza de la gente (cf. v. 4c). La situación descrita prepara el contraste entre el dābar del pueblo y el dāabar de YHWH que presenta Is 63,1e. La diferencia entre uno y otro es fortísima y tiende a exaltar el carácter único de la palabra del Señor, como alternativa válida a la confianza puesta en la nada (bātô $\left.\hat{o}^{a} \boldsymbol{h}{ }^{6} a l-t \bar{o} h \hat{u}, 59,4 \mathrm{c}\right)$.

A nivel discursivo, el profeta se dirige siempre al mismo grupo de personas. Pero su denuncia pasa de la acusación directa, "ustedes", en $2^{\text {a }}$ m. p. (vv. 2-3), 35 a una descripción amarga de la situación generalizada (v. 4) que constata: "no hay siquiera uno (y se sobreentiende 'de ustedes') que invoque la justicia o juzgue con lealtad". Su juicio categórico se prolonga luego hasta el v. 8, pero de modo indirecto; ahora el profeta habla de "ellos" (en 3 m. p., vv. 5-8), como si se dirigiera a otro grupo de gente, o reflexionara la denuncia realizada. ${ }^{36} \mathrm{~A}$ favor de esta última posibilidad se puede argumentar por lo que sigue: Is 59,5-6 estructura cuidadosamente dos imágenes que ilustran plásticamente la segunda parte del v. 4. ${ }^{37}$

Los huevos de víbora (bêșê șip ‘ônî, v. 5a), incubados por el grupo, muestran la peligrosidad de la maldad que conciben, y de la iniquidad que alumbran (v. 4e.f). El resultado final es que sus obras, o matan (v. 5c.d), o envenenan (v. 5e.f). Las telas de araña (qûrê 'akkābî̌s, v. 5b) que ellos mismos tejen, señalan la precariedad de las mentiras en las que confían (v. 4c.d). Sus soluciones son puros enredos que finalmente dejan desnudo al que intenta cubrirse con ellas (v. 6a), sin que siquiera les sirvan de coartada para tapar las iniquidades ('’̄wen, vv. 4f.6c) en las que se empeñan.

Is 59,6d.7a vuelve a relacionar los pecados del pueblo con el cuerpo humano. En el v. 7, las imágenes de los pies, del camino, y de los "planes de iniquidad" (mah̆še bôt 'āwen, v, 7d), relacionan el pecado con la conducta humana. A nivel estilístico, los lexemas kap ("las palmas de las manos",

35. 'ăwōnōtêkem, "las culpas de ustedes"; bênēkem, "entre ustedes"; 'ёlōhêkem, "el Dios de ustedes"; mikkem, "de ustedes"; kappêkem, "las palmas de las manos de ustedes"; 'eșb $\boldsymbol{b}^{\boldsymbol{e}} \hat{\mathrm{o}}$ têkem, "y los dedos de ustedes"; śiptôtêkem, "los labios de ustedes"; $\boldsymbol{l}^{\boldsymbol{e} \mathbf{s} \boldsymbol{o}} \boldsymbol{n}^{\boldsymbol{e}} \mathbf{k e \boldsymbol { m }}$ " "la lengua de ustedes".

36. ma ắsêhem, "sus obras" (v. 6b[2x]); raglêhem, "sus pies" (v. 7a); mahšebôtêhem, "sus maquinaciones" (v. 7d); mesillôtām "sus caminos" (v. 7e); $\boldsymbol{m a}^{\boldsymbol{a}} \boldsymbol{g}^{\boldsymbol{e}} \mathbf{l o ̂ t a ̄ m}$ " "sus sendas" (v. 8b); $\boldsymbol{n}^{\boldsymbol{e}}$ hîbôtêhem, "sus senderos"; lāhem, "para ellos" (v. 8c).

37. H. Simian-Yofre, Isaia 56-66. Dispense per uso esclusivo degli studenti, Roma 2004,74 , señala la composición de los dos términos en dos versos y un desarrollo de dos versos para cada uno de los términos iniciales. 
vv. 3a.6d), 'āwen ("iniquidad", vv. 4e.6c), y dām ("sangre", vv. 3a.7c) conforman una inclusión. El ámbito temporal del futuro, que predomina entre los verbos de los vv. 5-9, imprime a la descripción cierto fatalismo. Los acontecimientos se presentan como algo definitivo e inexorable. Así, sus pies correrán inevitablemente hacia lo que esté mal (raglêhem lāra' yārușû, v. 7a), y se apurarán (wimahărû) a derramar sangre inocente.

Por su parte, los caminos del pueblo - derek, v. 8a y sus sinónimos: mesillāh, v. 7e, $\boldsymbol{m a}^{\prime} \boldsymbol{g} \bar{a} \boldsymbol{l}$, v. 8b, $\boldsymbol{n}^{e} \boldsymbol{t} \hat{\boldsymbol{b}} \boldsymbol{b} \overline{\boldsymbol{a}} \boldsymbol{h}$, v. 8c- presentan características marcadamente negativas: son pura "destrucción y quebranto" (̌̌ $\overline{\boldsymbol{o}} d$ wašeber, v. 7c). En ellos "no existe el derecho" (we'ên mǐ̌păt, v. 8b), y han sido torcidos a favor de sus hacedores por ellos mismos ('āqaš Piel perfecto $3^{\text {a }}$ c. p. + prep. $l^{e}$-dativus commodi- + suf. $3^{-\frac{a}{m}}$. p.). Pero ni los que los idean, ni los que los recorren, conocerán el šâlôm (v. 8a.d.e; cf.

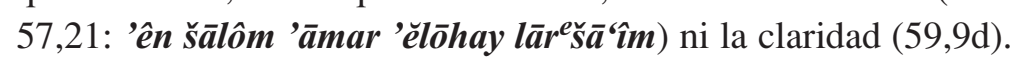

Finalmente, las mah̆š́ bôt (v. 7c) tienen que ver con las acciones deliberadas y planificadas en orden a conseguir una finalidad determinada. El sustantivo mahăšs̆ābāh, "pensamiento", "plan”, "propósito”, es un término de uso más bien poético y tardío. Deriva de la raíz ḥāšab (“pensar", "planificar", estimar") y aparece nueve veces en cuatro pasajes de Isaías: En Is 55,7.8.9 (invitación a la conversión, Is 55,6-11), el II Isaías exhorta al pueblo a la conversión y búsqueda del Señor $(55,7)$; pide que el malvado abandone su camino (darkôo), y el inicuo "sus maquinaciones" (mah̆šbōtâw). El sentido de la expresión es claramente negativo. Pero hay una dificultad: en ese mismo pasaje se usa para señalar "los planes" del Señor (con sentido positivo, cf. vv. 8.9).

Por su parte, el III Isaías, en 65,2 (denuncia y amenaza de Dios a su pueblo, Is 65,1-7), asocia la rebeldía del pueblo con el mal camino que transitaba para llevar a cabo "sus planes" ('ahar mahšebōtêhem; con sentido negativo). Pero en Is 66,18 (oráculo sobre la reunión de todos los pueblos, Is 66,18-24), "los planes" aparecen asociados a las obras del pueblo (ma“ăśêhem ûmah̆š́bōtêhem) y transformados por la venida del Señor (con sentido positivo).

Así, los diversos matices del sustantivo mahăăs̄ăbāh provienen, no del contexto en el que se insertan, sino de la autoridad moral de aquellos que son sus artífices. En Is 59,7 (denuncia de los pecados de Israel, Is 59,1-8), "los planes" tienen una valencia marcadamente negativa: están asociados al camino que los malvados trazan con inquina, y para su propio beneficio.

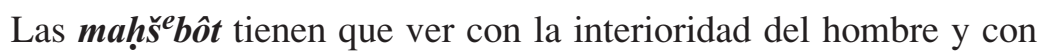
su actividad intelectual. Así, con la denuncia profética de los "planes" urdidos por el hombre, el pueblo queda comprometido totalmente -de pies a cabeza- en una conducta reprobada por Dios y denunciada por el III Isaías.

La expresión 'al-kēn, "por eso", al inicio de 59,9, introduce la apódosis del oráculo, que se extiende hasta el v. 15a. En ella es posible diferenciar dos partes: la primera se caracteriza por el uso del "nosotros" (vv. 9-11.12); la segunda describe los pecados asumidos por el pueblo (vv. 1315a). El v. 12 hace de bisagra entre ambas: comparte las características gramaticales de la primera, e indica la asunción de la culpa que introduce la nueva descripción de los pecados que él bien conoce. La primera parte trasluce una profunda decepción, especialmente manifestada en los vv. 9c.d.11c. En ellos el profeta constata la diferencia existente entre la luz, la claridad y el derecho que se espera ( $q \overline{\boldsymbol{a}} \boldsymbol{w} \overline{\boldsymbol{a}} \boldsymbol{h}$ Piel imperfecto $1^{\underline{a}}$ c. p.) y la realidad de oscuridad, de tinieblas, de ausencia del derecho, y de lejanía de la salvación que se evidencia ya a partir del v. 4. El III Isaías, único interlocutor del oráculo, se hace cargo y asume también él las culpas del pueblo.

El adverbio 'ayin, "no hay", "no existe", aparece siete veces en todo el capítulo; remarca las carencias que se constatan, especialmente, en relación con el ámbito del derecho y de la justicia (vv. 4a.b.8a.11d.15f.). El verbo rāhaq, "estar lejos", "alejarse" (Qal perfecto, vv. 9a.11d; prep. min + adjetivo, v. 14b), se predica del derecho (v. 9a), la salvación (v. 11d) y la justicia (v. 14b), como si el pueblo fuese mero espectador de la situación.

A nivel estructural, rāhaq y mišpāt forman un quiasmo entre el inicio del v. 9 y el final del v. 11; ambos lexemas están acompañados por la prep. min + sufijo de 1 c. p., "de nosotros". Esta expresión, junto con el

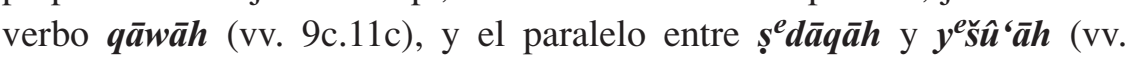
9b.11d), conforman una inclusión que encuadra los sentimientos de desilusión, parálisis, desaliento, falta de claridad, confusión, fragilidad, bronca y murmuración, experimentados por el pueblo no sólo frente a la situación apenas descrita, sino también frente a Dios (vv. 12-13).

La situación es compleja y, más allá de la tesis inicial, no tiene viso de solución. Los vv. 14-15a sólo confirman esta impresión: los valores fundamentales para el cambio -el derecho, la justicia, la verdad, la rectitud-han sido borrados hasta tal punto del tejido social, que si alguien trata 
de apartarse del mal -no se trata siquiera de pretender cambiar las cosas aunque, ciertamente, podría ser un inicio-, acaba siendo despojado (15b).

\subsection{La injusticia que apura la salvación}

De repente, todo este panorama fatalista y deprimente con que se describe la realidad, queda superado por el anuncio de los vv. 15c-20; por la pura iniciativa de Dios. La solución que se encuentra a la cantidad y complejidad de los problemas planteados parece ocurrir por arte de magia. Pero refleja la mentalidad apocalíptica que, por una parte, tiende a recrear la confianza de las víctimas de la injusticia; 38 y por otra, presenta su perspectiva de solución a las situaciones que urge remediar: la única posibilidad de que las cosas cambien, real y definitivamente, es a través de una intervención extraordinaria del Señor, que imponga en ellas el orden de su justicia.

Dentro del horizonte textual de Is 63,1-6, destaca especialmente la relación de nuestro poema con Is 59,15c-20. Los dos pasajes presentan rasgos propios de la imaginación apocalíptica y sus perspectivas de solución frente a los problemas que presenta la cruda realidad; aunque no llegan a conformarse como literatura apocalíptica. ${ }^{39} \mathrm{Si}$ bien aluden a situaciones diversas, los dos textos se reclaman, se complementan mutuamente entre sí y se ubican el uno en función del otro. A nivel estructural,

38. En este sentido, la traducción propuesta por Rofé para 59,19b daría en la clave para explicar el sentido de la teología de la redención en el III Isaías, en la misma línea de lo que aquí se expresa, a pesar de lo conjetural de su propuesta. Cf. A. Rofé, "Isaiah 59:19 and Trito-Isaiah's Vision of Redemption", The Book of Isaiah - Le livre d'Isaie. Les oracles et leurs relectures unité et complexité de l'ouvrage, BEThL LXXXI, 1989, 407 410. J. Vermeylen (Du Prophète Isaie à l'Apocalyptique. Isaie, I-XXXV, miroir d'un demimillénaire d'expérience religieuse en Israël, EtB, Paris - 1977, II, 469-470.489-490) ve en 63,1-6 la relectura de 59,15b-20 y la interpretación de todo el capítulo 59. Para este autor, "Edom" es el representante del opresor de la comunidad de los justos; según él, el redactor de estos versículos pensaba en los Moabitas, Edomitas y Amonitas que se habían mezclado al pueblo de la tierra durante la época de la deportación y de los cuales los judíos paganizados eran considerados por él herederos.

39 Para las características específicas de la apocalíptica en cuanto literatura, cf. J. J. Coluns, "Introduction: Towards the Morphology of a Genre", Semeia 14 (1979) 1-20. Varios puntos reseñados por él se encuentran a lo largo de la predicación del III Isaías. Aquí destaca la situación de maldad imperante que será destruida por la acción de Dios o su actividad judicial. HANSON, Dawn, 1-31, 132, indica que Is 59 es un punto importante en el desarrollo que lleva de la escatología profética a la escatología apocalíptica; parte enmarcan el mensaje central del III Isaías (60-62) y se relacionan con Is 61,1-3a que describe la unción del Espíritu y la misión del profeta.

Is 59,16 e Is 63,5 tienen la misma organización: un verbo de

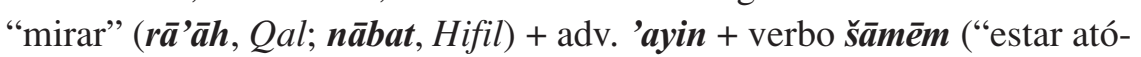
nito", Hitpolel) + adv. 'ayin. En ambos el sujeto de la acción es el Señor. Pero, mientras en 59,16 el profeta habla de él (verbos en $3^{3}$ m. s.), en nuestro texto es YHWH mismo quien narra su hazaña (1 ${ }^{\text {a }}$ c. s.). En Is 59,15c.d,

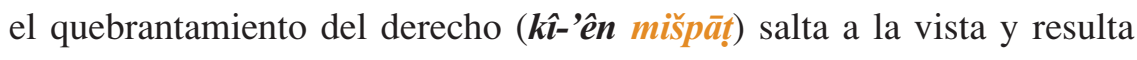
insoportable ante los ojos de Dios. El verbo $\boldsymbol{r} \overline{\boldsymbol{a}} \boldsymbol{\overline { a }} \boldsymbol{h}$, "ver", predicado dos veces del Señor (vv. 15c.16a), confirma, por una parte, la sentencia inicial del oráculo (v. 1), y por otra, evidencia la cercanía de Dios que ve lo que sucede en la comunidad jerosolimitana e interviene decisivamente en la situación. El adverbio 'ayin resalta que, en ambas oportunidades, Dios acomete por sí mismo una empresa heroica: en Is 59 contra los opresores del pueblo y en Is 63, contra los pueblos opresores. Is 59,16a.c constata

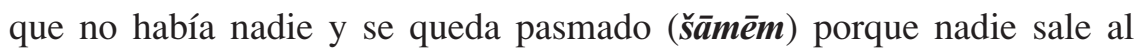
encuentro de la situación, para cambiarla (pāga ${ }^{6}$, Hifil participio m. s.); esto lo lleva a tomar la situación en sus manos. Para Is 63,5b.d, en cambio, el motivo del asombro es que nadie "de los pueblos", lo ayudara, o apoyara en su empresa.

Las segundas partes de Is 56,16; 63,5 difieren sólo en lo que sostiene a YHWH en ese momento: en 59,16e, "su justicia", mientras, en 63,5f., "mi furia". En Is 63,3c.6b hẹemāh indica la violencia desplegada por el Señor, al actuar su venganza contra las naciones. En 59,18a.b, es lo que YHWH promete a sus adversarios y enemigos ( $\left.\boldsymbol{l}^{\boldsymbol{e}} \mathbf{a} \overline{\boldsymbol{a}} \boldsymbol{a} \hat{\boldsymbol{a}} \boldsymbol{w}, \boldsymbol{l}^{\boldsymbol{e}} \overline{\boldsymbol{o}}^{\boldsymbol{e}} \boldsymbol{b} \hat{\boldsymbol{a}} \boldsymbol{w}\right)$ que, en este caso, no son las naciones extranjeras, como en 63,6a (a pesar que el texto hebreo, a diferencia del griego, haga referencia también a "las islas" como destinatarias de su paga). El contexto inmediato de Is 59,15c20 hace pensar más bien en una purga al interno de la comunidad jerosolimitana. Con todo, sus efectos tienen una repercusión universal $(59,19)$.

La alusión al $\boldsymbol{z}^{\boldsymbol{e}} \boldsymbol{r} \overline{\boldsymbol{o}} \boldsymbol{a}^{\boldsymbol{c}}$, al "brazo del Señor", es coherente con el uso que Isaías da a este lexema. De las 16 veces que se presenta en todo el libro, sólo en dos oportunidades está referido al cuerpo humano (Is 17,5;

de un proceso histórico continuo de readaptación del Yahwismo a las diversas coyunturas vividas por el pueblo de Israel en el post-exilio del Segundo Templo. La opinión de CROATTO, Imaginar, 334, aparece, en cambio, un tanto desenfocada, al ver en la síntesis explicativa de 63,6a el pasaje que engancha la imaginación con el plano histórico. 
44,12); el resto de las veces indica siempre el brazo del Señor como sinónimo de su poder y en contextos de salvación. 40

Is 59,17 anuncia justamente cómo Dios se prepara para salvar y para liberar a su pueblo, desde dentro. Movido por la indignación de su amor apasionado, se viste como un guerrero: como armadura usa su

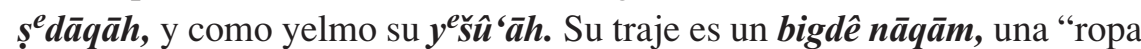
de venganza", y el manto que lo envuelve es su celo (qin'āh). Se trata justamente de lo que falta y se hecha de menos en Jerusalén a causa del pecado: liberación, salvación y venganza. Los vestidos tienen relación con la ropa del Dios Guerrero que en Is 63,1b.c.2.3d.e se presentan ensangrentados por la batalla. 41

La venganza ( $\boldsymbol{n} \bar{a} q \overline{\boldsymbol{a}} \boldsymbol{m}$ ) que en $59,17 \mathrm{~b}$ es el traje que el Señor viste para esta ocasión especial, en 63,4a tiene que ver con su día (como en $61,2)$. Junto con los otros atuendos señala su actitud fundamental y el carácter específico de su intervención. Así, en ambos oráculos, se trata de una obra de justicia: hacia dentro de la comunidad jerosolimitana del postexilio, en 59,18.20; y hacia afuera de ella, en 63,4a.6. Is 63,1-6 trasciende la Jerusalén del profeta, mientras que Is 59,15c-20 mira al quebrantamiento del derecho dentro de ésta. El concepto de "venganza" aplicado a parte del pueblo del Señor, implica que Dios no sólo lo desconoce como su propiedad, sino también niega ser el redentor de parte de Israel, considerándolos como asesinos de los que ha de vengarse. Con todo, Is

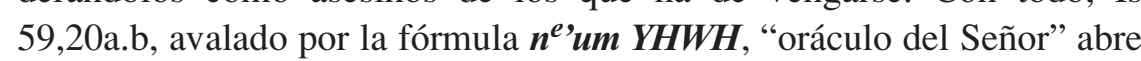
la puerta de la redención y la esperanza de la salvación para los descendientes de Jacob que se conviertan de la propia rebeldía.

Finalmente, el v. 21 va más allá de la indignación y coloca la purificación prometida como condición necesaria para una nueva alianza, que es pura gratuidad de Dios para con el pueblo que se ha rescatado: la unción de su Espíritu y las palabras confiadas por el Señor al profeta

40. Cf. Is 9,$19 ; 30,30 ; 33,2 ; 40,10 ; 48,14 ; 51,5$ (2x). 9; 52,10; 53,1; 59,16; 62,8; $63,5.12$.

41. El campo semántico del vestir está dominado por los lexemas derivados de läbaš junto con beged. La poesía de estos pasajes lo usa con sentido metafórico, de acuerdo al estilo antropomórfico normal que condiciona el lenguaje propio de las comparaciones y las visiones. Cf. E. JeNNI, "לבעש", THATI, 1185-1188.
(61,1-2) permanecerán en sus labios y en los de sus descendientes para siempre $(59,21)$.

Otro texto significativo, y en algunos aspectos, comparable a Is 59, especialmente por la promesa de salvación a un pueblo obstinado y apartado de la salvación, es Is 46,12-13 (oráculo sobre la ineficacia de los ídolos y la fidelidad de Dios, Is 46). Allí, el Señor se manifiesta dispuesto a intervenir, él mismo e inmediatamente, para traer la liberación a su pueblo y a Sión, su salvación. El mensaje está dirigido, justamente, a aquellos que tienen el corazón endurecido y están lejos de la justicia ('abbîrê

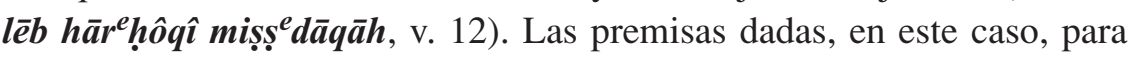
animar la confianza del pueblo se basan, por un lado, en que ha sido él quien ha creado y sostenido permanentemente a su pueblo (46,3-4); por otro, en la eficacia de su palabra, que lleva a cumplimiento lo que anuncia (v. 10).

EN RESUMEN. Los contactos de Is 59 con nuestro texto reafirman la perspectiva de la salvación como iniciativa suprema y exclusiva del Señor en favor de su pueblo, justo cuando nada ni nadie parece alentar esta esperanza. El horizonte textual queda explícito desde el inicio del oráculo: "El Señor está siempre dispuesto a salvar" (v. 1a). Pero la profecía enseña también cómo sin justicia no hay salvación, y cuál es la responsabilidad que le cabe al pueblo por la presencia de la no-salvación que los aflige: "las culpas de ustedes han abierto un abismo entre ustedes y su Dios" (v. 2a). El oráculo aborda de lleno la problemática de la injusticia en la comunidad jerosolimitana del post-exilio y descubre los sentimientos que despierta en el pueblo la confrontación del profeta.

El pueblo, sumido en el pecado, es responsable de la coyuntura contra la que murmura culpando a Dios. Es demasiado frágil para hacer frente a la situación; mas cuando es capaz de asumir su pecado, paradójicamente -o, quizás, justamente a causa de ello-, el Señor, indignado, se viste para la guerra y se apresta a intervenir para castigar a los culpables, rescatar a los convertidos, y establecer con ellos una nueva alianza.

Si en cierto momento, las culpas y pecados denunciados por el III Isaías, y reconocidos por el pueblo, parecían haber frenado indefinidamente la llegada de la salvación a Jerusalén, estancándola para siempre en la no-salvación, la criminalidad y la mentira, la iniciativa divina muestra todo lo contrario: es esta misma situación la que determina su venida. Dios en persona se prepara a cumplir su promesa. La solución de la perspectiva apocalíptica nos deja perplejos. La salvación tiene ahora un carác- 
ter más restringido. El pecado ha dividido al pueblo por la mitad, y la llegada de la salvación se parece más a un juicio, que a la antigua esperanza de vida prometida a todos los habitantes de Sión, durante el exilio.

\subsection{El juicio del Señor, consuelo para el pueblo}

La misma perspectiva judiciaria de salvación asume Is $66,14 \mathrm{~d}-15$ frente a la llegada del Señor. El pasaje presenta pocos lexemas en común con nuestro texto; pero es sobretodo el contexto el que lo ubica dentro del mismo horizonte textual:

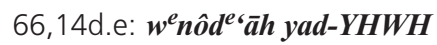

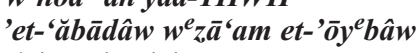

(el poder del Señor se mostrará

a sus fieles, pero estará indignado

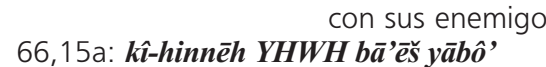
(he aquí que el Señor llegará

66,15b: lehošîb b' hēmāh 'appô con fuego) (para desahogar el ardor de su ira)

63,1e: ănî...rab lehôšria ${ }^{\text {‘ }}$

(Soy yo... el poderoso salvador)

63,5e: wattôša' lî $z^{e} \boldsymbol{r} \overline{\boldsymbol{o}}^{\top} \hat{\imath}$

63,1a: $\boldsymbol{m i ̂}-\boldsymbol{z} \boldsymbol{e h} \boldsymbol{b} \bar{a}^{\prime}$

(= así que me salvó mi brazo)

(¿Quién es ese que está llegando?)

63,5 f: wahămātî hî̀' $\boldsymbol{s}^{\boldsymbol{e}} \boldsymbol{m a \overline { a }} \boldsymbol{k a} t \boldsymbol{t} \hat{\imath}$

(y mi furia fue la que me sostuvo) 63,3c: we' $^{e}$ erm $^{e}$ sèm bahămāt

63 6b: (y los aplasté con mi furia) (los he emề bahămāt

(los he emborrachado con mi furia)

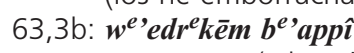

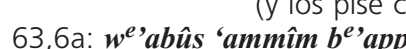

(he pisoteado los pueblos con mi rabia)

Is $66,14 \mathrm{~d}-15$ forma parte de un oráculo de juicio sobre Jerusalén (Is 66,5-17). Está dirigido a "los que tiemblan ante la palabra del Señor" (haḥărēêim 'el-d'bārô, v. 5a). El adjetivo verbal ḥārēd, "tembloroso", indica en el III Isaías, un sujeto preferencial de la atención del Señor: "Yo me fijaré en éste: en el humilde y en el de espíritu abatido, que tiembla ante mi palabra" (Is 66,2c), y con quienes él Señor se había ya identificado en 57,15 (= oráculo de consuelo y salvación, Is 57,14-21). Se trata de un grupo bien definido dentro de la comunidad jerosolimitana, pero que es objeto de escarnio para sus hermanos (cf. v. 5b).

Dos repeticiones importantes del adjetivo hārēed se presentan en el libro de Esdras. La expresión $\boldsymbol{k} \overline{\boldsymbol{o}} \boldsymbol{l}$ ḥārēed $\boldsymbol{b}^{\boldsymbol{e}}$ dibrê 'ĕlōhê-yiśrā'ēl (Esd 9,4a) describe al grupo reunido junto a Esdras cuando, informado de la unión matrimonial entre los repatriados y la población mestiza del país, queda desconsolado (Esd 9,1-4). A ese grupo parece pertenecer incluso el mismo

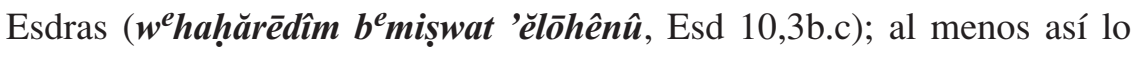
reconocen los israelitas en el templo, cuando se comprometen a expulsar las mujeres extranjeras, y los hijos nacidos de ellas, "según el consejo del Señor y de los que tiemblan con los mandamientos de nuestro Dios" (Esd 10,1-15). La relación existente entre el grupo de Esdras, "la gente del país" ( "am-hāa'âres, Esd 4,4) y "los temblorosos" de Is 66,2c.5a es una empresa que excede el presente análisis. Con todo, el problema señalado evidencia dos mentalidades en pugna por el servicio del culto y la práctica religiosa en Jerusalén, desde el momento en que se inicia la reconstrucción del santuario (cf. Esd 4,1-5; Is 56,3-8).

Is 66,7-9 describe la restauración de Jerusalén con la imagen del parto: la ciudad da a luz un pueblo (v. 8) y el Señor deja nacer (v. 9). Como una madre consuela a su hijo, él lo consolará en Jerusalén, (v. 13). Y su consuelo será motivo de alegría tanto para Jerusalén como para todos los que la aman; y para quienes, por ella, están de luto (vv. 10.14a.b.c). El consuelo del Señor consiste en que él llegará, de modo inminente, con sus "carros de guerra" (mark $\boldsymbol{e} \boldsymbol{b} \overline{\boldsymbol{o}}$, v. 15a) para desahogar la furia de su ira contra sus enemigos (de dentro), los idólatras y los sacerdotes de los ídolos (vv. 14e.15b.17). Este pueblo, sujeto preferencial del amor del Señor, es también el destinatario de la misión para la cual el III Isaías ha sido ungido con el Espíritu.

\subsection{El ministerio del anuncio y del consuelo}

Is 61,1-3a presenta dos reclamos lexicográficos con nuestro texto: la expresión yôm nāāam, "día de venganza"; y el sustantivo šānāh en estado constructo, "año de" (Is 61,2a; 63,4). ${ }^{42}$ Pero es sobre todo el contenido de la misión -anunciar y consolar- el que puede iluminar aún más el horizonte textual de Is 63,1-6.

La unción descrita en Is 61,1a recuerda la irrupción del Espíritu que capacitaba a los antiguos jueces de Israel para que llevaran a cabo su misión. ${ }^{43} \mathrm{Al}$ III Isaías lo habilita para anunciar buenas noticias a los aba-

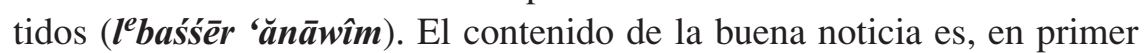

42. Ambos han sido ya considerados en el presente trabajo, a propósito del "Ambiente semántico" (cf. 4.2 .3 y 4.2.4).

43. Cf. Otniel (Jue 3,10), Gedeón (Jue 6,34), Jefté (Jue 11,29), Sansón (Jue 13,25). Y lo mismo sucede con Saúl (1 Sam 10,1.6. 10) y David (1 Sam 16,13). 


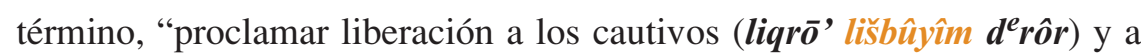

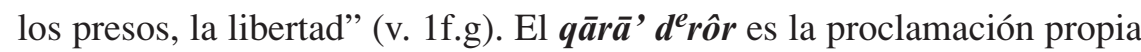
del año jubilar (cf. Lv 25,10), una ley social instaurada para restituir la fraternidad en el país, y la dignidad perdida de las personas en régimen de esclavitud. Los destinatarios del anuncio del III Isaías están todos signados por el abatimiento, la aflicción y las heridas del corazón. Se trata de los “ănāwîm, ("abatidos", v. 1c); los nišberê-lēb, ("quebrantados”, v. 1f); los šebûyîm, ("cautivos", v. 1g); los 'ăsûrîm ("prisioneros", v. 1h); todos los 'ăbēlîm, "los que hacen duelo" (v. 2b); y los 'ăbēlê șiyyôn, "los afligidos de Sión” (v. 3b). La proclamación es, en sí misma, palabra de consuelo; porque anuncia un cambio de situación. Tiene un fuerte contenido social y está orientada a vendar las heridas del pueblo que sufre, a cambiar sus cenizas por una corona, su luto por perfumes de fiesta y su tristeza por cantos de alabanza. Los efectos de esa misión se pueden ver en el oráculo de salvación que se presenta en Is 61,3b-9: “serán llamados encinas de justicia".

Pero el año jubilar, en cuanto práctica concreta del pueblo, como tantas otras leyes sociales, parece no haberse cumplido ni una sola vez en Israel. ${ }^{44}$ Y cuán difícil ha sido para el profeta superar la simple retórica de la misión encomendada, se puede ver por su invocación, en 63,14b-17. En nombre del pueblo que Dios ha adquirido, el III Isaías invoca directamente la paternidad divina sobre ellos; porque no son reconocidos como hijos de Abraham, e Israel los rechaza. Su clamor es el grito de un hombre angustiado: "¡Tú eres nuestro Padre!... Desde siempre te invocamos como nuestro redentor" (63,16a.d.e). Con su lamento, el III Isaías intercede por el pueblo ante Dios, asumiendo sobre sí la misión encomendada a los centinelas: recordar al Señor sus propias promesas (Is 62,6-7).

\subsection{Recapitulación sobre el horizonte textual de Is 63,1-6}

Is 63,1-6 es el único texto, en todo el III Isaías, en el que la promesa de la salvación y el ejercicio de la justicia divina se presentan como ya cumplidos por el Dios Guerrero. La venganza contra los pueblos ha tenido lugar en Edom; y el Señor, solo, ha rescatado la sangre inocente derramada, a través de la purificación por la sangre de los asesinos. Si el

44. Cf. J. A. SogGIN, "Il giubileo e l'anno sabatico", http://www.biblico.it/docvari/conferenza_soggin.html [acceso: 26.10.2005].
Salvador Victorioso, luego de haber actuado en Edom, se presenta ahora a las puertas de Jerusalén, es porque su presencia trae a la ciudad la realidad de la salvación anticipada en 62,11. Se acerca para rescatar en ella a su pueblo santo $(62,12)$. Para hacer realidad la libertad de los cautivos y la alegría de los afligidos de Sión. Para hacer cumplir la proclamación misionera del III Isaías (61,1-3a).

Mas la relación de nuestro texto con Is 59,15c-20 es muy fuerte y la salvación del Señor se presenta también como una realidad de juicio inminente, prometido en 59,15c-20 y repropuesto en 66,14 b-16 como cierre del libro. El juicio traerá fuego y "serán muchos los traspasados por el Señor" (66,15a.16b.c). Pero también traerá alegría para Jerusalén y los que la aman. Para todos los que por ella están de luto $(66,10)$; pues la ciudad quedará liberada de sus enemigos. ${ }^{45} \mathrm{Y}$ cuando el juicio haya pasado, el Señor será el inspirador de las obras y los planes del pueblo, en una nueva realidad por él trasformada (66,18-20), y transformada también para quienes hayan accedido a la bienaventuranza: los que se hayan mantenido fieles en el ejercicio del derecho y en la práctica de la justicia; los que hayan observado el sábado absteniéndose de la criminalidad (56,1-2); los que se hayan convertido de su maldad $(59,20)$, los de espíritu quebrantado $(57,15)$; y los que tiemblan ante la palabra del Señor $(66,5)$.

La revelación y comprensión de este plan divino de salvación bien puede ser el fruto de una visión del profeta, imbuida del espíritu apocalíptico, ante la situación angustiante que se vive en la ciudad. Pero la claridad de la visión demora en concretarse; por eso su recuerdo angustiado de las promesas al Dios de la promesa, mientras la justicia y la salvación tardan en llegar a Jerusalén.

\section{El Sitz im Leben}

Los estudios realizados a propósito del complejo y aún debatido proceso de composición literaria del libro en su conjunto han confirmado la pluralidad de autores, perspectivas teológicas, estilos y coyunturas por las que ha pasado el texto de Isaías tal como ha llegado a nosotros. Diversas e igualmente plurales han sido las propuestas tendientes a identificar al autor de cada una de sus secciones: 1-39; 40-55; 56-66. Por eso,

45. Así también Koole, Isaiah III, 329. 
hablar del "profeta" en el III Isaías es adoptar un modo convencional con el cual se pretende indicar al autor de estos capítulos; se trate de un personaje histórico: un profeta o vidente en torno al cual se ha congregado un grupo autodefinido como los ḥărêdîm, es decir, aquellos "que tiemblan" (ante su palabra) como señala J. Blenkinsopp; 46 "la comunidad” que está detrás del III Isaías, como entiende E. Achtemeier; ${ }^{47}$ un autor-profeta anónimo que guarda su anonimato preservando la tradición isaiana como el II Isaías; ${ }^{48}$ un redactor-productor puramente literario destinado a prolongar el mensaje contenido en el conjunto de Is 1-55, como indica la hipótesis de J. Vermeylen; ${ }^{49}$ o alguien que realiza un primer ejercicio hermenéutico del mensaje del II Isaías aplicándolo a las cambiadas circunstancias en las que se vive, algo así como un sermón o un comentario sobre un "texto sagrado" según considera R. N. Whybray. 50 Comoquiera que fuese, hay que reconocer con B. S. Childs que su obra es un mensaje de Dios frente a una coyuntura histórica determinada. ${ }^{51}$ Una palabra que va más allá del preciosismo literario de la obra producida y que da cuenta de una realidad concreta que no sólo no le resulta indiferente, sino que además toma partido en ella contándose entre las víctimas.

Algunos estudios "acrónicos" del texto ${ }^{52}$-como el exquisito ensayo de R. Lack- permiten inferir del texto su Sitz im Menschen. Así dan cuenta del articulador universo antropológico y humano en él contenido. ${ }^{53}$ Pero lo concreto de las situaciones descritas por el III Isaías y las acusaciones que realiza en estos capítulos, son demasiado tangibles. En base a ellas, P. Hanson ha postulado una hipótesis articulada y verosímil

46. Cf. J. Blenkinsopp, Storia della Profezia in Israele, BiBi(B) 22, Brescia - 19973, 265. 47. Cf. E. Achtemeler, The Community and Message of Isaiah 56-66. A Theological Commentary, Minneapolis - 1982, 16.

48. Cf. CHILDS, Isaiah, 443.

49. Cf. J. VermeYLen, "L'unité du livre d'Isaie", The Book of Isaiah - Le livre d'Isaie. Les oracles et leurs relectures unité et complexité de l'ouvrage, BEThL LXXXI, 1989, 44.

50. Cf. WHYBRAY, Isaiah, 39.

51. Cf. CHILDS, Isaiah, 443.

52. Cf. H. Simian-Yofre, "Acronía. Los métodos estructuralistas", Metodología del Antiguo Testamento (ed. H. Simian-Yofre), Biblioteca de Estudios Bíblicos 106, Salamanca - 2001, 127-143.

53. Cf. R. LACK, La Symbolique du livre d'Isaie. Essai sur l'image littéraire comme élément de structuration, AnBib 59, Roma - 1973, 252. sobre el Sitz im Leben del III Isaías; ${ }^{54}$ un aspecto al que la lectura propuesta por B. Childs no concede mayor importancia. 55

El análisis del horizonte textual de Is 63,1-6 ha puesto en evidencia el contraste que existe entre el anuncio de la salvación y la justicia inminente y su retraso, con lo que esta situación genera en el profeta y en el pueblo. Las injusticias, la mentira y los crímenes, dividen a la comunidad jerosolimitana y la hunden en una situación que inmoviliza hasta la desesperación. El recorrido por Is 56-66 permite detectar al menos dos grupos enfrentados entre sí: las víctimas -entre los que se cuentan el profeta y su gente, que observan lo que sucede desde el margen en el que se encuentran desplazados $(59,21 ; 64,15 b .16)$-, por un lado; y por otro, quienes mantienen la situación tal como está. 56 Se podrían discriminar incluso dos niveles de marginalidad y culpabilidad en ambos grupos respectivamente: las estrictamente sociales y las de tipo religioso. Pero el profeta no hace este tipo de disquisiciones. En las acusaciones morales que lanza contra el segundo grupo se juega tanto la lealtad de la comunidad jerosolimitana al Señor, la verdadera identidad de quienes se consideran "su pueblo" sin serlo, como la de aquellos otros que siendo hijos de Dios, son marginados sin consideraciones por la comunidad creyente $(64,16)$.

El cambio de situación anhelado por el profeta y su grupo es en orden a un doble cumplimiento de las promesas del Señor: las que realiza

54. Cf. HANson, Dawn, 94-100.220-228. Cf. algunas críticas dignas de consideración en BLENKINSOPP, Storia, 258-259; 264, n. 37; 265, n. 38.

55. Cf. CHILDS, Isaiah, 444.448-449.

56. Si se toma en cuenta is 56-59 (ya que Is 60-62 refleja otro tipo de situación cargada de entusiasmo y optimismo; y 63-66 refleja una atmósfera parecida a la del primer bloque), en el primer grupo se cuentan: los extranjeros y eunucos "que se han unido al Señor" (56,3.4.6); los marginados de Israel $(56,8)$ : hombres justos y piadosos $(57,1)$; pueblo arrepentido y humilde del Señor $(57,14 \mathrm{~b} .15 \mathrm{~b})$; trabajadores explotados (58,3b); gentes oprimidas (58,6b); hambrientos, sin techo ni vestidos $(58,7)$. En el segundo, los pastores $(56,11)$ e idólatras que, olvidándose del Señor, van detrás de otros dioses $(57,3-13)$; los malvados $(57,20)$; los que se consideran un pueblo recto, "descendencia de Jacob", y quieren conocer los caminos del Señor $(58,2)$, pero cuya piedad está viciada desde su misma raíz porque todo les da lo mismo (v. 3), son explotadores (v. 4), peleadores, criminales $(58,4 a ; 59,3 a .7 a)$ y mezquinos (v. 7). Con ellos están los que acusan fraudulentamente $(58,9 b ; 59,3-4)$; los que prefieren negocios y paseos en lugar de la observancia del sábado (v. 13); los que sólo abren senderos torcidos $(59,8)$ y saquean al que se aparta del mal $(59,15)$. 
“en esa circunstancia” la proclamación profética del III Isaías (por el profeta mismo o por la lectura de su texto), recogiendo las acentuaciones éticas propias del Yahwismo que han de acogerse con corazón humilde y arrepentido $(56,8 \mathrm{~b} ; 57,2.13 ; 58,8 \mathrm{~s} .11 \mathrm{~s} ; 59,21){ }^{57}$ y aquellas otras, más parecidas a las del II Isaías, con una perspectiva aún más acentuadamente nacionalista, de los capítulos 60-62, cuyas posibilidades parecen estar condicionadas por el cumplimiento -o no cumplimiento- de las primeras. 58

Según E. Achtemeier -que sigue con acentos propios la hipótesis de P. Hanson- la clave para el abordaje del Sitz im Leben de "la comunidad" es la promesa hecha por el Señor en Is 66,21: "Me elegiré también de entre ellos (los pueblos extranjeros) sacerdotes levitas". 59 Así, detrás de las acusaciones, el verdadero motivo que causa división en la comunidad es la pugna entre dos facciones por el ejercicio del culto (y el poder) en la ciudad santa. ${ }^{60}$ Por un lado, el "partido sadoquita, hierocrático-monárquico"; por otro, el "partido levítico, teocrático-profético”. El primero se remonta a Sadoc, hijo de Ajitub y el segundo a Abiatar, hijo de Ajimélec, ambos sacerdotes de David (2 Sam 8,17). La mayoría de los sadoquitas habrían conocido el destierro luego de la caída de Jerusalén, mientras la mayoría del segundo grupo habría permanecido en el país devastado (Esd 2,36-40 // Ne 7,39-43; 12,1-9; 1 Cr 9,10-16) manteniendo su servicio cultual en Jerusalén -modelado, según P. Hanson, de acuerdo al pensamiento del II Isaías-61 con sacrificios (Ez 44,6-9) y liturgias penitenciales ( $\mathrm{Za} \mathrm{7,1-15;}$

57. H. Simian-Yofre, Isaías. Texto y comentario, El Mensaje del Antiguo Testamento 12, Madrid - Salamanca - Estella, 1995, 31, considera que probablemente la oración de Is 63,7-64,11 sea el texto más propio y teológicamente elaborado del III Is.

58. En este sentido, son dignas de consideración las referencias de HOLMGREN, "Avenger", 137-148, sobre la unidad del autor de Is 56-66 y nuestro texto de 63,1-6.

59. Un texto que, tomado en su contexto $(66,18-24)$, junto a $56,1-8$ y $58,13-14$, es considerado por Hanson, Dawn, 101, parte del armazón redaccional.

60. Cf. Achtemeier, Community, 17-26

61. W. Brueggemann ("Trajectories in Old Testament Literature and the Sociology of Ancient Israel", The Bible and Liberation. Political and Social Hermeneutics [ed. N. K. Gottwald], Maryknoll - 19842, 307-333) contextualiza ambas facciones como dos "trayectorias" o tendencias identificables -por su teología y su sociología de base- a lo largo de todo el recorrido histórico del pueblo de Israel, desde su génesis, en el perído mosaico, hasta el post-exilio. Este abordaje interpretativo podría ser, según este autor, un nuevo paradigma para los estudios biblicos; consideración que iría en la misma línea de la hermenéutica y pragmalingüística que propone H. SIMIAN-YOFRE, "Anacronía y sincronía. Hermenéutica y pragmática", Metodología, 177-201. 8,18s). De este modo los levitas habían recuperado su ministerio sacerdotal en la capital; ya que habían sido reducidos a clero de segunda clase después que Salomón expulsara a Abiatar de Jerusalén desterrándolo a Anatot, por haber sostenido a su hermano Adonías como legítimo sucesor al trono de David, su padre (1 Re 2,22s. 26s); en esa misma categoría quedaron confirmados los levitas por la ley de Ezequiel (Ez 44,10-31).

Éste es el cuadro situacional en que se ubica nuestro texto. No hay modo de saber quién fue su autor -tal vez el mismo de los demás escritos- o detallar las circunstancias precisas que dieron a luz estos seis versículos. El marco que brinda Is 63,1-6 (junto a 59,15b-20), refleja el anhelo apocalípticamente realizado de un grupo doblemente oprimido, que reclama para sí su derecho al ejercicio del sacerdocio en el templo del país, como ver colmadas las esperanzas de restauración para Jerusalén. Pues si bien es cierto que el regreso del destierro había ya tenido lugar, no menos cierto es que la realidad distaba enormemente del entusiasmo que lo había alentado; y muy pronto el pequeño círculo del profeta se encontró dominado y perseguido por el sacerdocio sadoquita que controlaba el culto nacional. ${ }^{62}$ Estos capítulos podrían ser datados, siguiendo el consenso de la crítica, aproximadamente en el 520 a.C.

Según Hanson, así fue creciendo la dificultad de ver la restauración como renovación del Israel histórico en la Jerusalén histórica; porque el Israel histórico se había vuelto una asamblea manchada y la Jerusalén histórica se había contaminado sobremanera por un culto condenado por YHWH. La realidad contrastaba flagrantemente con las grandes esperanzas que había despertado en ambos grupos la llegada de Ciro al poder y el regreso de los exiliados. Ahora se imponía la necesidad de una nueva época en la cual la intervención de Dios hiciera cierta su justicia y liberara, con el ejercicio de su poder, a los que aún seguían esperando una intervención que arrancara de cuajo a los enemigos de su pueblo, y terminara con la dominación del tutelaje extranjero de los persas.

62. Para W. Brueggemann, Isaiah 40 - 66, Westminster Bible Companion, Louisville - 1998, 164-165, la obra del III Is podría ser el reflejo de la crisis teológica propia del nacimiento del judaísmo: entre el 520-516 a.C., cuando comienza la reconstrucción del templo y la restauración de la comunidad de la ley propiciada por Esdras y Nehemías en el 444 a.C., sin que haya existido realmente un culto en Jerusalén durante el exilio y sin ningún trauma ocasionado al volver de éste, pero asumido a través de esta producción literaria como "construcción social". 


\section{La imagen de Dios de Is 63,1-6 en la perspectiva teológica de Isaías}

La imagen de Dios que presenta nuestro texto asume la perspectiva de los oráculos contra las naciones; particularmente de los anuncios contra Edom, de finales del exilio e inicios del post-exilio. Evoca al Dios Guerrero de los cantos épicos de Israel; al Dios de la Justicia; al Dios que cumple la palabra empeñada; al Dios Liberador de su pueblo; al Dios que remedia la fraternidad traicionada.

El III Isaías asume la tradición de los grandes profetas de Israel; especialmente las del Primer y Segundo Isaías. Por el discernimiento orante de la palabra y la tradición de ellos recibida, busca iluminar, desde dentro, es decir, compartiendo los anhelos y angustias de su grupo apocalíptico, la nueva coyuntura que atraviesa su comunidad.

El Dios del consuelo para el Israel del destierro, el redentor del pueblo, el creador y hacedor de maravillas ${ }^{63}$ por medio del cual la poderosa imaginación del II Isaías alentaba la esperanza de su gente en medio de la calamidad, tiene ahora un margen de acción más acotado. La vuelta del destierro ya ha tenido lugar, pero no ha traído aún la luz esperada. Todavía late en medio del pueblo la esperanza encendida por la promesa de una nueva Jerusalén y un futuro luminoso para Israel, con Dios amaneciendo su gloria sobre él $(60,2)$. Pero las promesas contrastan demasiado con la dura realidad de opresión que viven los fieles del Señor.

Por eso, el ejercicio de la justicia divina en Edom está orientado, fundamentalmente, a alentar la esperanza de este pequeño grupo en la comunidad dividida de Jerusalén, tomando parte en sus peleas y sus divisiones internas. El Dios Guerrero y Victorioso sobre las naciones, en toda su fuerza -él solo como un héroe luchando contra el mundo-, es evocado en Is 63,1-6 como indicador y agente de cambio en medio de una situación desesperante. ${ }^{64}$ Sólo él puede cambiar la situación intestina que ha marginado al grupo apocalíptico de la escena central del templo, lugar que había reivindicado en los últimos años. Si el Señor ha cumplido realmente su palabra, como es cierto que lo hará, y a través de su venganza ha ejer-

63. Dios de Consuelo: Is 40,1; 51,12; 52,9; 49,13. Redentor: Is 43,1.14; 44,6.22.24; 47,$4 ; 48,17 ; 49,7.26$. Creador del universo y del pueblo de Israel: 40,12-14.26.28; $41,4.18-20 ; 42,5 ; 43,1.19 ; 44,2.21 .24 ; 45,9-12.18 ; 48,7$

64. 'ên-lîs, "sin nadie", es una de las expresiones preferidas de Isaías: 41,28; 50,2; 57,$1 ; 59,16 ; 63,3$. cido sus rescates, hay motivos ciertos para esperar y confiar en que también podrá rescatar al pequeño resto que sufre.

Is 63,1-6 sintoniza así con el Primer Isaías que, en el contexto de la guerra Siro-Efraimita, cuando el corazón del rey y de todo su pueblo temblaba "como tiemblan los árboles del bosque sacudidos por el viento" (Is 7,2), le dirigió a Ajaz esta palabra de parte del Señor: "Si no confían en mí no subsistirán" (7,9b). La fuerza y la potencia del Salvador Victorioso en Is 63,1-6 son no sólo ni principalmente una imagen del Dios que aniquila a sus enemigos con el poder de su brazo sino, y ante todo, un icono del Dios que sostiene al pueblo que sufre, dándole razones para resistir esperando en él. Su justicia es el don de su misericordia paterna a una comunidad que reconoce su pecado y la persistencia del mismo $(64,4 \mathrm{~b})$; a una comunidad que sabe que su Dios está "siempre dispuesto a salvar y su oído pronto a escuchar" $(59,1)$ a quien, en ella, sea capaz de emprender el duro proceso de asumir las propias culpas - personales y comunitarias- e invocar el auxilio del Señor, consciente de su propia indigencia. El Sitz im Leben señalado por el contexto amplio de Is 63,1-6 permite acercar nuestro texto a la profecía transmitida por el profeta en Is 29,9-10.1114 a los videntes de su época: "Dejen que transcurra el tiempo (esperando que se cumpla la profecía) y (entonces) quedarán asombrados". 65

\section{Conclusión}

Este trabajo ha buscado responder a los múltiples interrogantes que suscita Is 63,1-6. Las imágenes condensadas en él por la imaginación del profeta tienen una fuerza evocadora particular, que ha quedado de manifiesto. El poema articula en sus escasos seis versículos dos de los ejes más importantes de la proclamación del III Isaías: la llegada de la salvación y la revelación de la justicia, en una forma totalmente original, plasmada por la mentalidad apocalíptica del profeta.

El juicio a las naciones que YHWH ha llevado a cabo en "Edom" coloca a nuestro texto en la perspectiva del cumplimiento de las promesas proféticas del exilio y el post-exilio (Is 34, entre otros). Evoca en la

65. SimiAN-YofRe, Isaia 56-66, 75-76, señala como partes de dicho proceso justamente el paso de la constatación de los hechos objetivos $(59,9-10)$ a la realidad personal y comunitaria $(59,12-15)$ y finalmente a la confesión del propio pecado $(64,4 \mathrm{~b}-6)$ y la súplica humilde $(64,7-11)$. Cf. la traducción propuesta en SimiAN-Yofre, Teologia, 38-39. 
memoria de Israel la fraternidad traicionada, pero también es el símbolo de todas las opresiones extranjeras que niegan al pueblo la posibilidad de la vida. Su aniquilación constata por anticipado la suerte de todos los opresores del pueblo, que también son enemigos del Señor: los imperios fundados en la violencia y finalmente "devorados a filo de espada".

La avanzada aguerrida del Señor en el territorio del Sur, recoge los vestigios reservados en la memoria popular a las gestas épicas del Dios Guerrero que luchaba victorioso junto a sus héroes; cuando Israel era apenas un bosquejo del pueblo que ideaba el amor de YHWH; testimonio de un pasado posible y alternativo, enraizado en el yavismo de los orígenes.

Su llegada a las puertas de Sión indica que también para su viña (Is 5,1-7) "ha llegado "el día de YHWH", con su juicio de vendimia inminente; el tiempo del mosto y de la concreción de sus promesas, de amenazas y bienaventuranzas. Dios, que ha rescatado para sí al pueblo de su propiedad, reivindicando el honor de su nombre por el rescate de la sangre, con el brutal ejercicio de la violencia que ha ejercido contra las naciones extranjeras, ahora se apresta a rescatar, en Sión, a su pueblo fiel y marginado por sus connacionales. El horizonte de la salvación es más acotado y personal que en el tiempo del II Isaías.

Is 63,1-6 recrea la confianza en que el Señor vendrá de modo inminente para cumplir lo que les había prometido. Nuestro texto es un icono de la justicia divina, mensaje de salvación y consuelo para los que aún esperan el cumplimiento de las promesas; buena noticia para los pobres y consuelo para los afligidos de Sión (61,1-3a). El Señor, que ha ungido con su Espíritu al profeta, cumplirá la liberación prometida a los que en él confían. Si le ha bastado la fuerza de su brazo para aniquilar él solo a los pueblos, no irá a menos su poder para sostener la esperanza de los que confían en su palabra.

Mientras tanto, la comunidad jerosolimitana, desgarrada por el drama de dos mentalidades en pugna y el pecado de la injusticia, parece hundida en el desconcierto e incapaz de reaccionar. El III Isaías, como centinela de la ciudad santa, lleva adelante su ministerio misionero entre la denuncia del pecado y el anuncio del consuelo; entre la proclamación de la liberación y la angustia porque no hay uno que actúe con justicia; entre la esperanza que debe sostener y la dura realidad que debe asumir; suplicándole a Dios que se acuerde de sus promesas, mientras se demora la llegada de la salvación.

Carlos H. Verga, cmF carlosvergacmf@yahoo.com.ar

Córdoba, Argentina 